\title{
Implementation Plan for \\ Liquid Low-Level Radioactive Waste Tank Systems \\ at Oak Ridge National Laboratory \\ Under the Federal Facility Agreement \\ Oak Ridge, Tennessee
}

Date Issued-September 1994

\author{
Prepared by \\ Waste Management and Remedial Action Division \\ Oak Ridge National Laboratory \\ Oak Ridge, Tennessee
}

Prepared for

U.S. Department of Energy

Office of Environmental Restoration and Waste Management under budget and reporting codes EX 20, EW 20, and EW-31

MARTIN MARIETTA ENERGY SYSTEMS, INC.

managing the

Oak Ridge K-25 Site

Oak Ridge Y-12 Plant

Oak Ridge National Laboratory

under contract DE-AC05-84OR21400

for the

U.S. DEPARTMENT OF ENERGY
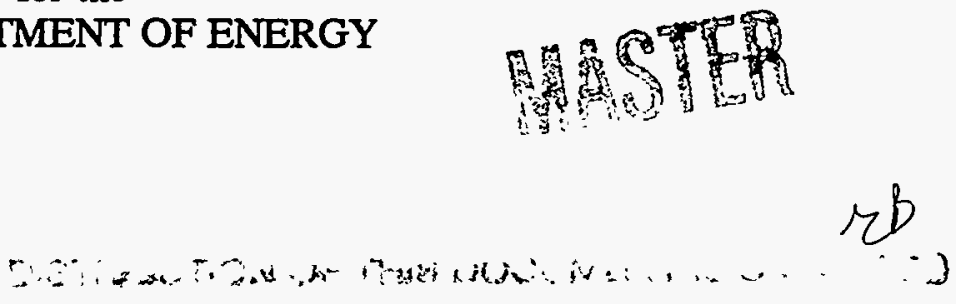


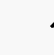




\section{DISCLAIMER}

This report was prepared as an account of work sponsored by an agency of the United States Government. Neither the United States Government nor any agency thereof, nor any of their employees, make any warranty, express or implied, or assumes any legal liability or responsibility for the accuracy, completeness, or usefulness of any information, apparatus, product, or process disclosed, or represents that its use would not infringe privately owned rights. Reference herein to any specific commercial product, process, or service by trade name, trademark, manufacturer, or otherwise does not necessarily constitute or imply its endorsement, recommendation, or favoring by the United States Government or any agency thereof. The views and opinions of authors expressed herein do not necessarily state or reflect those of the United States Government or any agency thereof. 


\section{DISCLAIMER}

Portions of this document may be illegible in electronic image products. Images are produced from the best available original document. 
$\underline{\text { Part }} \quad \underline{\text { Page(s) }} \quad \underline{\text { Rev. No. }} \quad \underline{\text { Date }}$ 

EXHIBITS $\ldots \ldots \ldots \ldots \ldots \ldots \ldots \ldots \ldots \ldots \ldots \ldots \ldots \ldots \ldots \ldots \ldots \ldots \ldots \ldots \ldots$

FIGURES $\ldots \ldots \ldots \ldots \ldots \ldots \ldots \ldots \ldots \ldots \ldots \ldots \ldots \ldots \ldots \ldots \ldots \ldots$

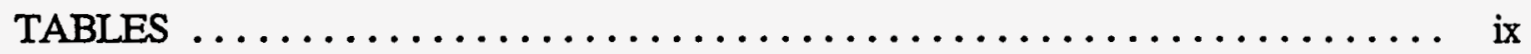

ABBREVIATIONS $\ldots \ldots \ldots \ldots \ldots \ldots \ldots \ldots \ldots \ldots \ldots \ldots \ldots \ldots \ldots \ldots \ldots$

GLOSSARY $\ldots \ldots \ldots \ldots \ldots \ldots \ldots \ldots \ldots \ldots \ldots \ldots \ldots \ldots \ldots \ldots \ldots \ldots \ldots \ldots \ldots$

EXECUTIVE SUMMARY $\ldots \ldots \ldots \ldots \ldots \ldots \ldots \ldots \ldots \ldots \ldots \ldots \ldots$

1. BACKGROUND $\ldots \ldots \ldots \ldots \ldots \ldots \ldots \ldots \ldots \ldots \ldots \ldots \ldots \ldots \ldots \ldots \ldots$

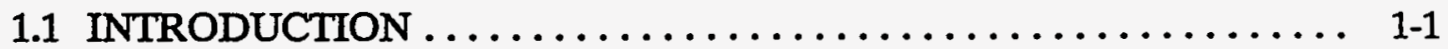

1.2 LLLW SYSTEM BACKGROUND $\ldots \ldots \ldots \ldots \ldots \ldots \ldots \ldots \ldots \ldots \ldots \ldots$

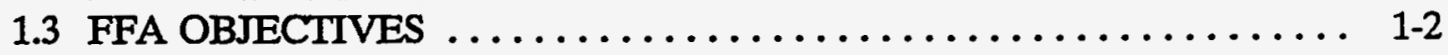

2. CATEGORY A TANK SYSTEMS $\ldots \ldots \ldots \ldots \ldots \ldots \ldots \ldots \ldots \ldots \ldots \ldots$

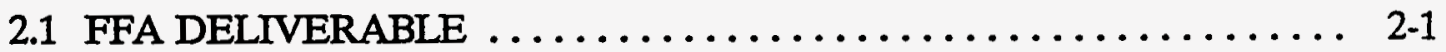

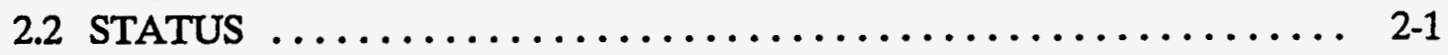

3. CATEGORY B TANK SYSTEMS $\ldots \ldots \ldots \ldots \ldots \ldots \ldots \ldots \ldots \ldots \ldots \ldots$

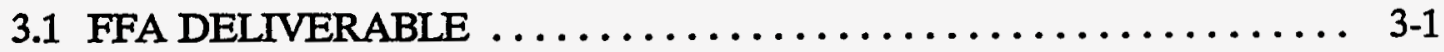

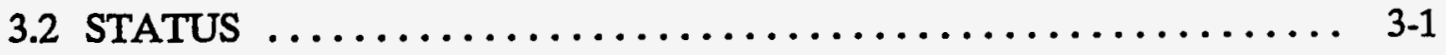

4. CATEGORY C TANK SYSTEMS $\ldots \ldots \ldots \ldots \ldots \ldots \ldots \ldots \ldots \ldots \ldots \ldots$ 4-1

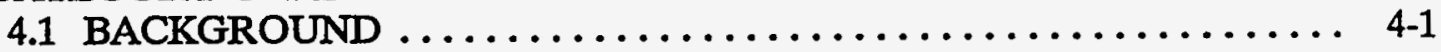

4.2 FFA DELIVERABLE $\ldots \ldots \ldots \ldots \ldots \ldots \ldots \ldots \ldots \ldots \ldots \ldots \ldots \ldots \ldots$ 4-1

4.2.1 Removal from Service ...................... 4-1

4.2.2 Structural Integrity Assessment ................ 4-1

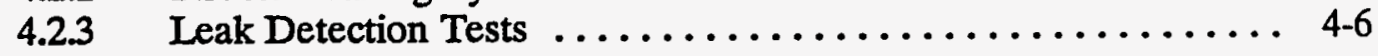

5. CATEGORY D TANK SYSTEMS $\ldots \ldots \ldots \ldots \ldots \ldots \ldots \ldots \ldots \ldots \ldots$ 5-1

5.1 WASTE CHARACTERIZATION SCHEDULE FOR THE CATEGORY

D TANK SYSTEMS $\ldots \ldots \ldots \ldots \ldots \ldots \ldots \ldots \ldots \ldots \ldots \ldots$. . . . . . .

5.2 RISK CHARACTERIZATION SCHEDULE FOR THE CATEGORY D

TANK SYSTEMS $\ldots \ldots \ldots \ldots \ldots \ldots \ldots \ldots \ldots \ldots \ldots \ldots \ldots \ldots . \ldots \ldots$

5.3 REMEDIATION SCHEDULE FOR THE CATEGORY D TANK

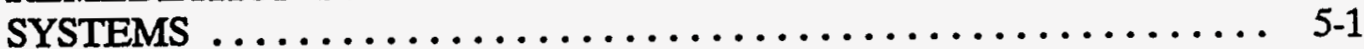

5.4 PROPOSED ACTIVITIES $\ldots \ldots \ldots \ldots \ldots \ldots \ldots \ldots \ldots \ldots \ldots \ldots \ldots \ldots$. $5-1$

5.4.1 Liquid Content Removal Schedule $\ldots \ldots \ldots \ldots \ldots \ldots \ldots \ldots . \ldots .6 . \ldots . \ldots$

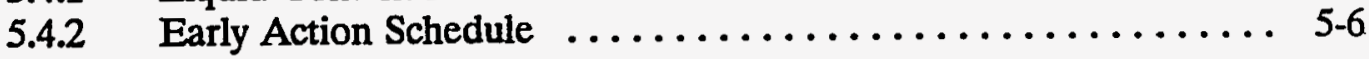

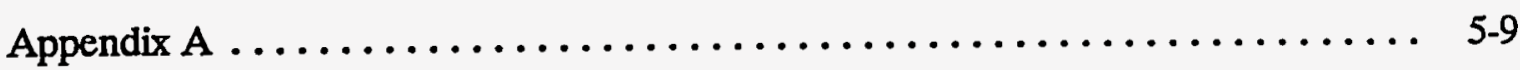

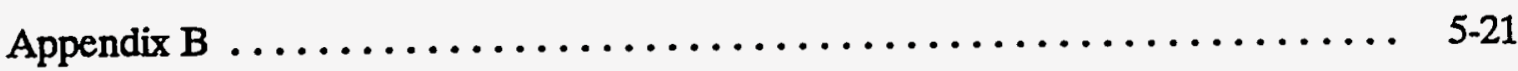

vii 


\section{EXHIBITS}

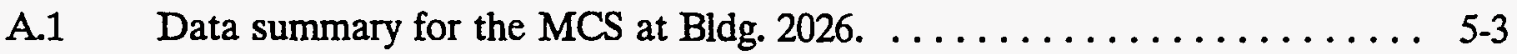

A.2 Data summary for the TWRF storage tank. . . . . . . . . . . 5-4

A.3 Data summary for the LLLW tank systems at Bldg. 3019 . . . . . . . . . 5-5

A.4 Data summary for the LLLW tank systems at Bldg. 3517. . . . . . . . 5-6

A.5 Data summary for the Evaporator Facility LLLW tank systems. . . . . . . 5-7

A.6 Data summary for the LLIW tank systems at Bldg. 3544 . . . . . . . . . 5 5-8

A.7 Data summary for the New Hydrofracture Facility LLLW tank system. . . . 5-9

A.8 Data summary for the Radiochemical Engineering

Development Center LLLW tank systems. . . . . . . . . . . . . 5-10

A.9 Data summary for the Melton Valley Storage Tank systems. . . . . . . . 5-11

A.10 Data summary for the LLLW tank systems at Bldg. 3525. . . . . . . . 5-12

A.11 Data summary for the Isotopes Circle Facilities LLLW tank systems. . . . 5-13

A.12 Data summary for the HFIR LLLW tank systems. . . . . . . . . . 5-14

A.13 Data summary for the ORR/BSR LLLW tank system. . . . . . . . . 5-15

A.14 Data summary for the LLLW tank system at Bldg. 3025. . . . . . . . 5-16

A.15 Data summary for the LLLW tank system at Bldg. 2533/3504. . . . . . . 5 5-17

A.16 Data summary for the Radioactive (Hot) Off-Gas LLLW tank system. . . 5-18

A.17 Data summary for the LLLW tank system at Bldg. 2026. . . . . . . . . . 5-19

A.18 Data summary for the LLLW tank system at Bldg. 3026D. . . . . . . . . 5-20

B.1 Data summary for South Tank Farm Category D LLLW tank systems. ... 5-3

B.2 Data summary for Old Hydrofracture Facility Category D

LLLW tank systems. . . . . . . . . . . . . . . . . . . . 5-5

B.3 Data summary for the North Tank Farm Category D LLIW tank systems. . 5-6

B.4 Data summary for the 3500 Area Category D LILW tank systems. . . . . . . 5-7

B.5 Data summary for the Isotopes Circle Category D LLLW tank systems. . . 5 5-8

B.6 Data summary for the 4500 Area Category D LLLW tank systems. . . . . . . 5-9

B.7 Data summary for the 3587 Area Category D LLLW tank systems. . . . . . 5-10

B.8 Data summary for Melton Valley Area Category D LLLW tank systems. . . 5-11

B.9 Data summary for the 3000 Area Category D LLLW tank systems. . . . . . 5-12

B.10 Data summary for the 3525 Area Category D LLLW tank systems. . . . . . 5-14

B.11 Data summary for the Bldg. 3047 LLLW tank systems. . . . . . . . . . 5-15 


\section{FIGURES}

1.1 Block flow diagram for the ORNL LLLW system $\ldots \ldots \ldots \ldots \ldots \ldots \ldots$

1.2 ORNL LLLW tank systems by FFA category $\ldots \ldots \ldots \ldots \ldots \ldots \ldots \ldots \ldots$

1.3 Bethel Valley LLLW tank system $\ldots \ldots \ldots \ldots \ldots \ldots \ldots \ldots \ldots \ldots \ldots \ldots$

$1.4 \quad$ Melton Valley LLLW tank systems $\ldots \ldots \ldots \ldots \ldots \ldots \ldots \ldots \ldots \ldots \ldots \ldots$

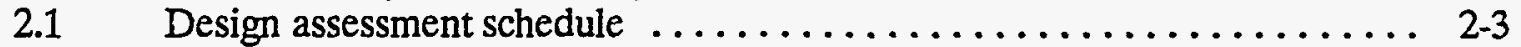

3.1 Secondary containment design demonstration schedule $\ldots \ldots \ldots \ldots \ldots \ldots$. $\ldots \ldots$

4.1 Structural integrity assessment schedule for tank systems not meeting secondary containment standards ............. 4-7

4.2 Leak testing schedule for Category $C$ tank systems $\ldots \ldots \ldots \ldots \ldots \ldots$

\section{TABLES}

2.1 Projects that will install Category A tank systems . . . . . . . . . . . 2-2

3.1 Projects for upgrading/replacing Category B LLLW tank systems . . . . . . 3-3

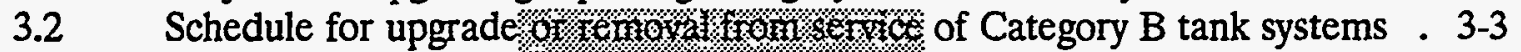

4.1 Projects for modifying FFA singly contained LLLW tank systems $\ldots \ldots \ldots$. $4-2$

4.2 Treatment projects for newly generated LLLW .............. $4-4$

4.3 Capital projects for FFA early actions for singly contained

LLLW tank systems . . ....................... $4-5$

4.4 Schedule for initiating leak testing of tanks $\ldots \ldots \ldots \ldots \ldots \ldots \ldots \ldots \ldots$

5.1 Status and planned activities for Category D LLLW tank systems . . . . . 5-2 
$\cdot$ 


\section{ABBREVIATIONS}

$\begin{array}{ll}\text { BSR } & \text { Bulk Shielding Reactor } \\ \text { CAT } & \text { collection and transfer } \\ \text { CERCLA } & \text { Comprehensive Environmental Response, Compensation, and Liability Act } \\ \text { CWCH } & \text { central waste collection header } \\ \text { DOE } & \text { U.S. Department of Energy } \\ \text { DOE-OR } & \text { DOE Oak Ridge Field Office } \\ \text { EPA } & \text { U.S. Environmental Protection Agency } \\ \text { ER } & \text { environmental restoration } \\ \text { ES\&H } & \text { environmental, safety, and health } \\ \text { FFA } & \text { Federal Facility Agreement } \\ \text { GAAT } & \text { gunite and associated tanks (OU) } \\ \text { GPP } & \text { general plant project } \\ \text { HEPA } & \text { high efficiency particulate air filter } \\ \text { HFIR } & \text { High Flux Isotopes Reactor } \\ \text { HRE } & \text { Homogeneous Reactor Experiment } \\ \text { HRLAL } & \text { High-Radiation-Level Analytical Laboratory } \\ \text { LIP } & \text { line item project } \\ \text { LLLW } & \text { liquid low-level radioactive waste } \\ \text { MCS } & \text { monitoring and control station (LLLW) } \\ \text { MVST } & \text { Melton Valley Storage Tanks } \\ \text { NHF } & \text { New Hydrofracture Facility } \\ \text { OHF } & \text { Old Hydrofracture Facility } \\ \text { ORNL } & \text { Oak Ridge National Laboratory } \\ \text { ORR } & \text { Oak Ridge Research Reactor } \\ \text { OU } & \text { operable unit } \\ \text { PWTP } & \text { Process Waste Treatment Plant } \\ \text { R\&D } & \text { research and development } \\ \text { RCRA } & \text { Resource Conservation and Recovery Act } \\ \text { REDC } & \text { Radiochemical Engineering Development Center } \\ \text { RI } & \text { remedial investigation } \\ \text { RI/FS } & \text { remedial investigation/feasibility study } \\ \text { RPPP } & \text { Radiochemical Processing Pilot Plant } \\ \text { RQ } & \text { reportable quantities } \\ \text { SIA } & \text { structural integrity assessment } \\ \text { TBD } & \text { to be determined } \\ \text { TDEC } & \text { Tennessee Department of Environment and Conservation } \\ \text { TRU } & \text { transuranics } \\ \text { TWRF } & \text { Transferred Waste Receiving Facility } \\ \text { WAG } & \text { waste area grouping } \\ \text { WM } & \text { Waste Management } \\ \text { WOCC } & \text { Waste Operations Control Center } \\ & \end{array}$




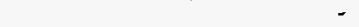




\section{GLOSSARY}

Category A. A new or replacement tank system with secondary containment.

Category B. An existing tank system with secondary containment.

Category C. An existing tank system without secondary containment.

Category D. A tank system that has been removed from service.

Hot cell. An enclosure and its associated ancillary equipment that provides shielding, containment, and remote handling capabilities for work involving radioactive sources and materials. Ancillary equipment includes radioactive off-gas filtration and drains to the LLLW system.

LLLW tank. A stationary device, designed to contain an accumulation of LLLW. It is constructed primarily of nonearthen materials (e.g., concrete or steel) to provide structural support and containment. This tank will function as a waste storage or neutralization tank. This definition does not include tanks in which processing other than neutralization occurs or in which the entire tank contents may be recycled to a process.

Leaking. The passage of a hazardous liquid through the primary or secondary containment structure at a rate greater than or equal to the criteria established in the Leak Testing Plan for the Oak Ridge National Laboratory Liquid Low-Level Waste System (ORNL/ER/SUb/92-SK263/1).

Raffinate. The part of a liquid remaining after its more soluble components have been extracted by a solvent.

Secondary containment tank system. For the purpose of the FFA, tank systems will be categorized as secondarily contained if the capability exists to contain regulated substances released from the primary tank system until such wastes are detected and removed. Some ORNL LLLW tank systems may require modification of ancillary equipment and the upgrade of secondary containment to meet FFA requirements.

Tank system. A waste storage or waste treatment tank and its associated ancillary equipment and containment system. In the ORNL LLLW system, ancillary equipment includes sumps, piping, and valves to the waste tank(s) and piping and valves from the waste $\operatorname{tank}(\mathbf{s})$. 
, 


\section{EXECUTIVE SUMMARY}

This document summarizes the progress that has been made to date in implementing the plans and schedules for meeting the Federal Facility Agreement (FFA) commitments for the Liquid Low-Level Waste (LLLW) System at Oak Ridge National Laboratory (ORNL). These commitments were initially submitted in ES/ER-17\&D1, Federal Facility Agreement Plans and Schedules for Liquid Low-Level Radioactive Waste Tank Systems at Oak Ridge National Laboratory, Oak Ridge, Tennessee. Information presented in this document provides a comprehensive summary to facilitate understanding of the FFA compliance program for LLLW tank systems and to present plans and schedules associated with remediation, through the Comprehensive Environmental Response, Compensation, and Liability Act (CERCLA) process, of LLLW tank systems that have been removed from service.

ORNL has a comprehensive program underway to upgrade the LLLW system as necessary to meet the FFA requirements. The tank systems that are removed from service are being investigated and remediated through the CERCLA process. Waste and risk characterizations have been submitted. Additional data will be prepared and submitted to EPA/TDEC as tanks are taken out of service and as required by the remedial investigation/feasibility study (RI/FS) process.

The plans and schedules for implementing the FFA compliance program that were submitted in ES/ER-17\&D1, Federal Facility Agreement Plans and Schedules for Liquid Low-Level Radioactive Waste tanks Systems at Oak Ridge National Laboratory, Oak Ridge, Tennessee, are updated in this document. Chapter 1 provides general background information and philosophies that lead to the plans and schedules that appear in Chaps. 2 through 5 . Thie How

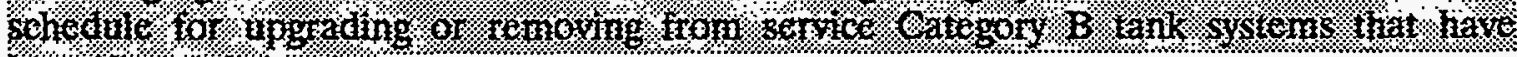
identified utetiotenciess

\section{SCHEDULE FOR REMOVING CATEGORY C TANKS FROM SERVICE}

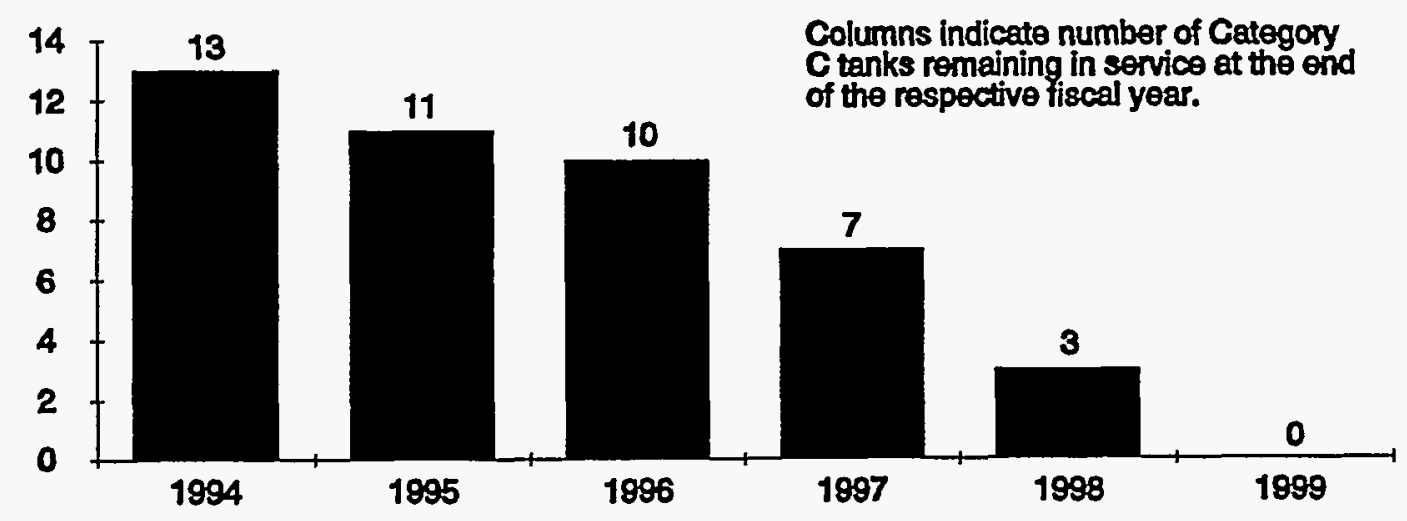




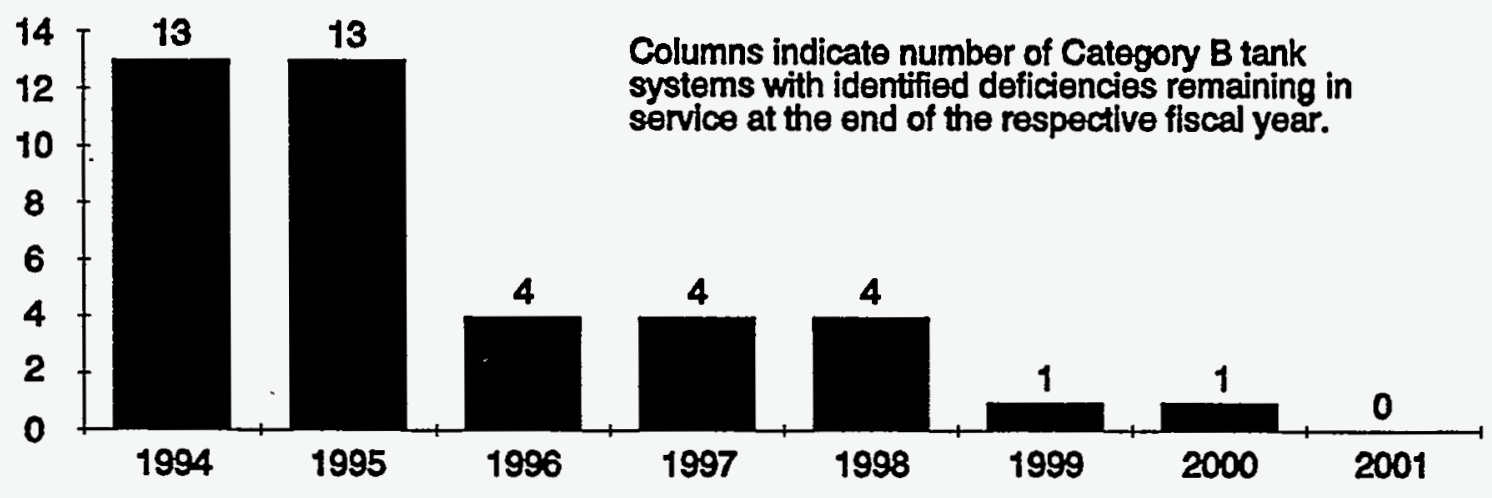

$m+m$

FISCAL YEAR

In the two years preceding the FFA effective date, 52 singly contained tanks were removed from service. Implementation activities during 1992 and 1993 are discussed in this document. Milestones achieved since the FFA became effective include submittal to EPA/TDEC of the following:

- a schedule for conducting secondary containment design demonstrations for doubly contained tank systems (ORO-91-331-001);

- a schedule for removing singly contained tanks from service (ORO-91-331-002);

- a schedule for periodic review and revision of the structural integrity assessments of singly contained tanks that temporarily remain in service (ORO-91-331-003);

- a schedule for evaluating the structural integrity assessments of singly contained tanks that temporarily remain in service (ORO-91-331-004);

- a schedule for providing waste characterization information for tank systems that are removed from service (ORO-91-331-005);

- a schedule for providing risk characterization information for tank systems that are removed from service (ORO-91-331-006);

- a plan for characterizing the risk for tank systems that are removed from service;

- the Leak Testing Plan for the Oak Ridge National Laboratory Liquid Low-Level Waste System (Active Tanks), ORNL/ER/Sub/92-SK263/1;

- the Waste Characterization Data Manual, DOE/OR/01-1159\&D1 (supersedes ES/ER-80) for the Category D tanks; 
- the Risk Characterization Data Manual ORNL/ER/Sub/90-W068/1 for the Category D tanks, first submittal;

- the Design Demonstrations Category-B Tank Systems, DOE/OR-1047;

- the Detailed Leak Detection Test Plan and Schedule for the Oak Ridge National Laboratory, LLLW Active Tanks DOE/OR/01-1129\&D1;

- Design Demonstration for the Remaining 19 Category B Tank Systems, DOE/OR/031150\&D1;

- the Remediation Schedule for Inactive Liquid Low-Level Waste Storage Tanks at ORNL, DOE/OR/01-1138\&D1;

- the Detailed Leak Detection Test Plan and Schedule for the Oak Ridge National Laboratory LLLW Active Pipelines, DOE/OR/01-1167 \& D1, September 1993;

- the Risk Characterization Data Manual ORNL/ER/Sub/90-W068/1 for the Category D tanks, final submittal; and

- the Design Demonstrations for Category B Tank System Piping at Oak Ridge National Laboratory, Oak Ridge, Tennessee, DOE/OR/03-1195\&D1, February 1993.

In addition to the submittals, the following actions have been accomplished:

- installed two new LLLW tanks serving Building 2026 and the transported waste receiving facility;

- removed singly contained tank LA-104 from service;

- initiated leak testing for all active, singly contained tanks and piping;

- eliminated two sources of non-LLLW inflow into tank WC-10;

- completed an ORNL-wide survey to identify inputs to the LLLW system that could be isolated or diverted to the process waste system;

- initiated projects to eliminate inputs to the LLLW system from the cell ventilation system and the hot off gas system, specifically, isolated the drains from the cell ventilation ducts and fans at the $\mathbf{3 0 3 9}$ central off gas stack, and the off gas condensate pots in the isotopes area;

- installed double wall pipe to bypass a leaking flange on the tank W-12 discharge line and submitted a request to use W-12 for decontamination of hot cells in Building 3525; and

- repaired leaking discharge line on tank WC-10. 
The tank systems at ORNL to which the FFA applies are listed in Fig. 1.2 of this report and in Appendix F of the FFA. Periodic changes occur in tank categories as tank systems are tested, upgraded or removed from service or for other reasons as agreed upon by the FFA signatories. Because of the time required to revise the FFA or this report, the lists in these documents may not reflect the latest approved status of some tanks. Any approved change in tank status that deviates from that shown in FFA Appendix F or this report will be supported by documentation on file in the Environmental Restoration Document Control Center and the Waste Management and Remedial Action Division Document Management Center. The FFA requirements applicable to each tank system are those for the latest approved category of that system. 


\section{BACKGROUND}

\subsection{INTRODUCTION}

The Superfund Amendments and Reauthorization Act of the Comprehensive Environmental Response, Compensation, and Liability Act (CERCLA) requires a Federal Facility Agreement (FFA) for federal facilities placed on the National Priorities List. The Oak Ridge Reservation was placed on that list on December 21, 1989, and the agreement was signed in November 1991 by the Department of Energy Oak Ridge Operations Office (DOE-ORO), the U.S. Environmental Protection Agency (EPA)-Region IV, and the Tennessee Department of Environment and Conservation (TDEC). The effective date of the FFA was January 1, 1992. Section IX and Appendix F of the agreement impose design and operating requirements on the Oak Ridge National Laboratory (ORNL) liquid low-level radioactive waste (LLLW) tank systems and identify several plans, schedules, and assessments that must be submitted to EPA/TDEC for review or approval. The issue of ES/ER-17\&D1 Federal Facility Agreement Plans and Schedules for Liquid Low-Level Radioactive Waste Tank Systems at Oak Ridge National Laboratory, Oak Ridge, Tennessee in March 1992 transmitted to EPA/TDEC those plans and schedules that were required within 60 to 90 days of the FFA effective date. This document updates the plans, schedules, and strategy for achieving compliance with the FFA as presented in ES/ER-17\&D1 and summarizes the progress that has been made to date. Chapter 1 describes the history and operation of the ORNL LLLW System and the objectives of the FFA. Chapters 2 through 5 contain the updated plans and schedules for meeting FFA requirements. This document will continue to be periodically reassessed and refined to reflect newly developed information and progress.

\subsection{LLLW SYSTEM BACKGROUND}

ORNL is a multidisciplinary research facility that began operation in 1943 as part of the Manhattan Project. The original mission of the laboratory was to develop a prototype graphite reactor and reprocess the reactor fuel for plutonium recovery. Subsequent to World War II, the primary functions of ORNL were fuel reprocessing research; radioisotopes production and applications development; and development, testing, and operation of nuclear reactor concepts. More recently, the laboratory has increased its role in biological, environmental, energy, and materials research. As a consequence of these multidisciplinary research activities, heterogeneous wastes, including solid and liquid radioactive, hazardous, and mixed wastes, have been generated in varying amounts over time.

Since its establishment, ORNL has operated numerous facilities that generate LLLW. LLLW originates from radioactive liquid discarded into sinks and drains in research and development (R\&D) laboratories and from facilities such as the Radiochemical Processing Pilot Plant (RPPP, Bldg. 3019), nuclear reactors, radioisotope production facilities, and the Process Waste Treatment Plant (PWTP),

The LLLW system is a complex system with multiple facilities, users, and operators. The system is used for collection, neutralization, transfer, and concentration of aqueous radioactive waste solutions from generator facilities, followed by storage of the LLLW 
concentrate. Figure 1.1 is a block flow diagram depicting the movement of waste through the system. Waste solutions are typically accumulated at source buildings, often in collection tanks located inside the buildings, and discharged to below-grade collection tanks that receive wastes from several different source buildings. However, in many instances, LLLW is transferred directly to underground collection tanks or the central waste collection header (CWCH) from laboratory and hot-cell drains through unvalved piping.

A network of below-grade piping interconnects the various system components. Because their initial $\mathrm{pH}$ may be low, LLLW solutions often must be neutralized with sodium hydroxide $(\mathrm{NaOH})$. The solutions are periodically transferred via the CWCH to the LLLW evaporator service tanks. From there, the solutions are sent to the LLLW evaporator facility where they are concentrated by a factor of approximately 30:1. The evaporator concentrate is then transferred via pipeline to the Melton Valley Storage Tanks (MVST). LLLW collection tanks are equipped with liquid-level instrumentation with high-level and low-level alarms to alert the Waste Operations Control Center (WOCC) of unusual conditions. The tanks are vented to the atmosphere through a central off-gas collection and filtration system operating at a negative pressure or through an individual tank filter system.

Most of the LLLW system was installed more than 30 years ago. The initial system and its subsequent modifications were designed to minimize radiation exposure to LLLW system users and operators. The system includes features such as unvalved, gravity-drained transfer lines to prevent waste backup into generator areas; shielded lines and tanks; and provisions for remote operations to minimize personnel exposure. As-built drawings for most of the older tank systems do not exist. Over the years, tank systems were abandoned as their integrity was breached or as programs were terminated. Some of the tanks were abandoned in place with liquid wastes and sludge left in them. As new tank systems were installed during the past 10 to 15 years, secondary containment and improved leak detection features were provided. The LLLW system is a mix of singly and doubly contained tank systems. The portions of the system that have been removed from service consist almost exclusively of tanks without secondary containment.

\subsection{FFA OBJECTIVES}

The objectives of the FFA are to ensure (1) that active tank systems slated to remain in service comply with the design and containment requirements specified in FFA Appendix F, Subsects. B and C; (2) that singly contained tank systems operated in the interim do not leak; and (3) that tank systems that are removed from service are evaluated and remediated through the CERCLA process. A breakdown of the LLLW tank systems by FFA category is provided in Fig. 1.2. Figures 1.3 and 1.4 are maps showing the relative locations of LLLW tanks under the FFA in Bethel Valley and Melton Valley, respectively. 


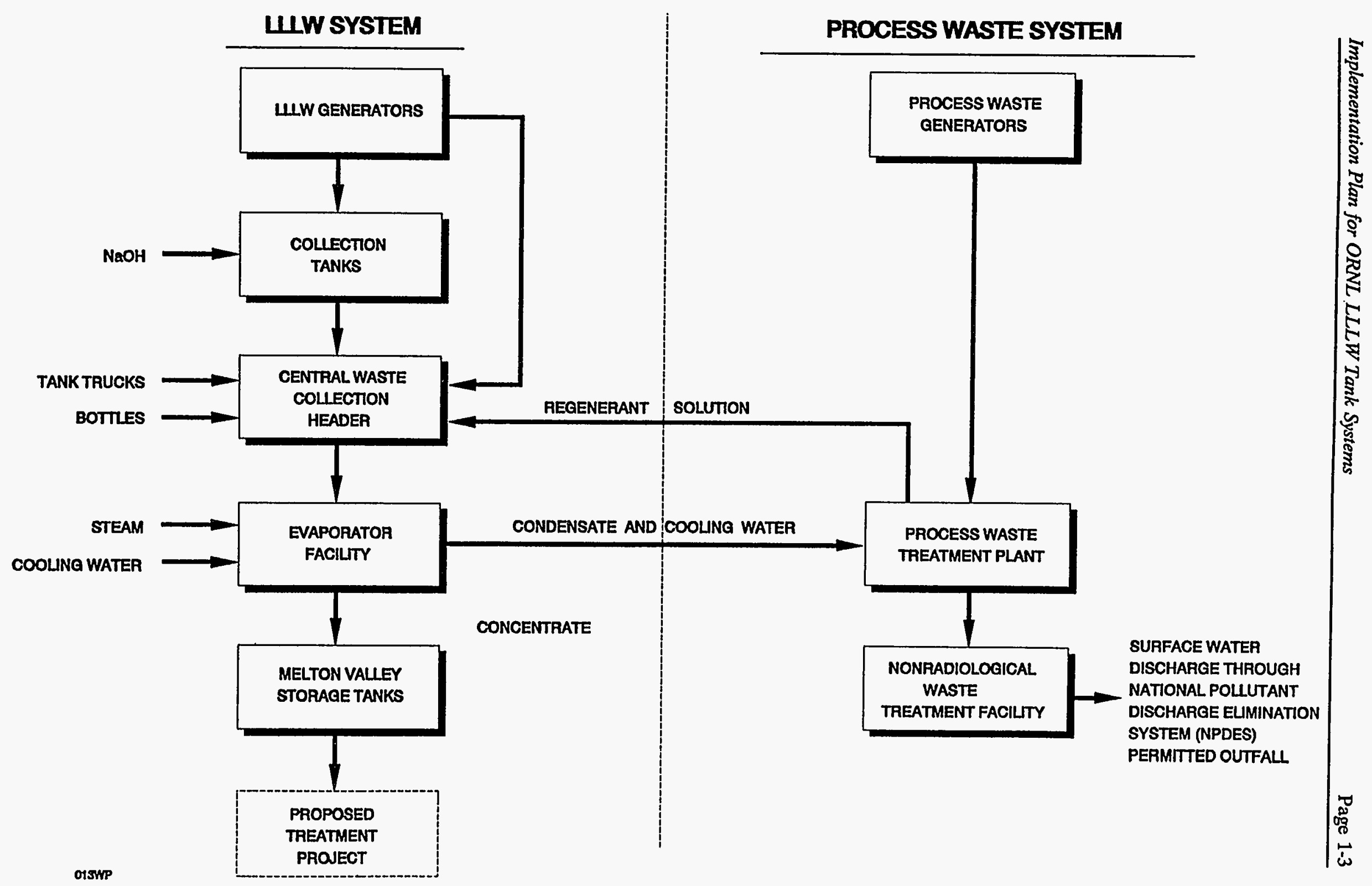

Fig. 1.1. Block flow diagram for the ORNL LLLW system. 


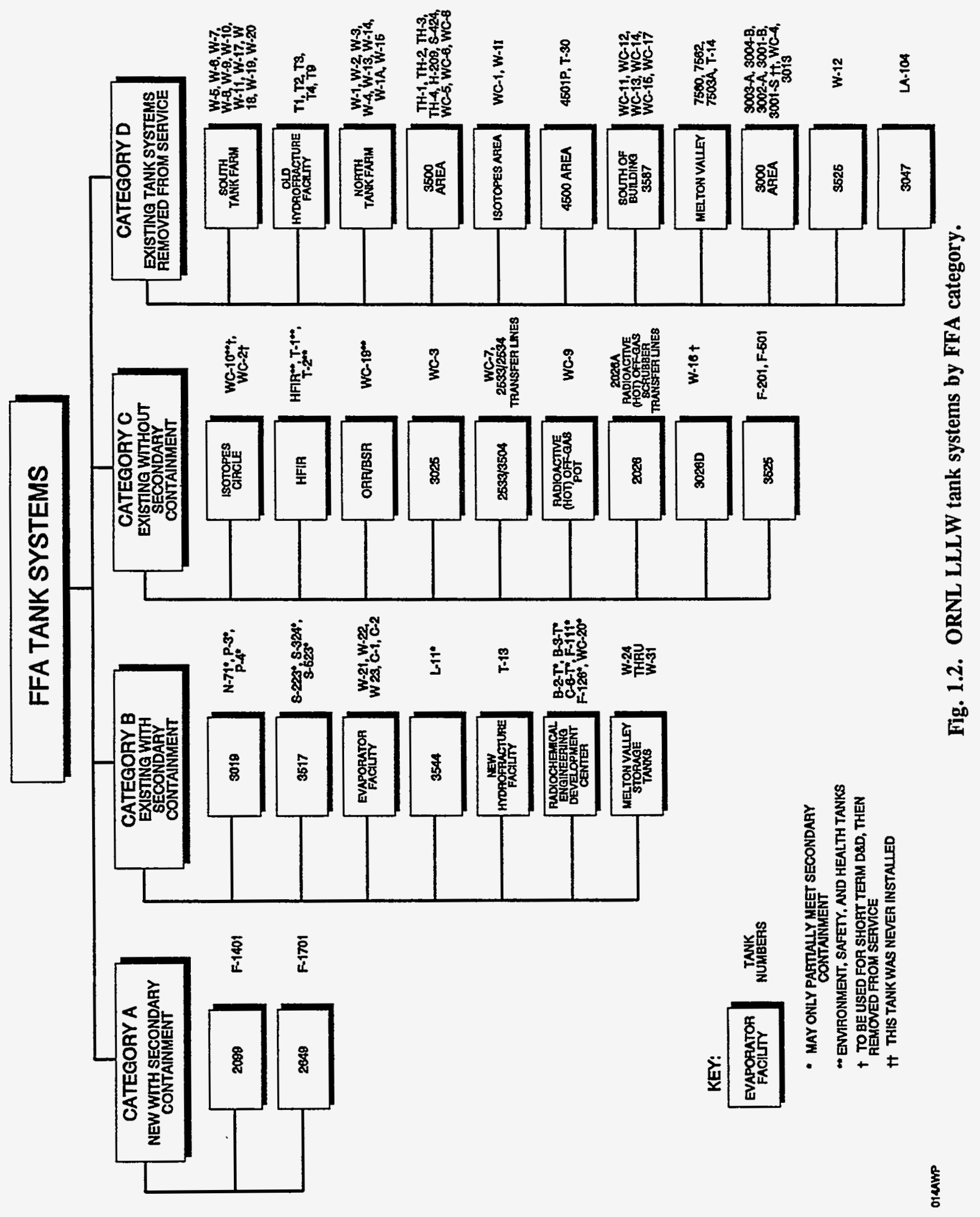




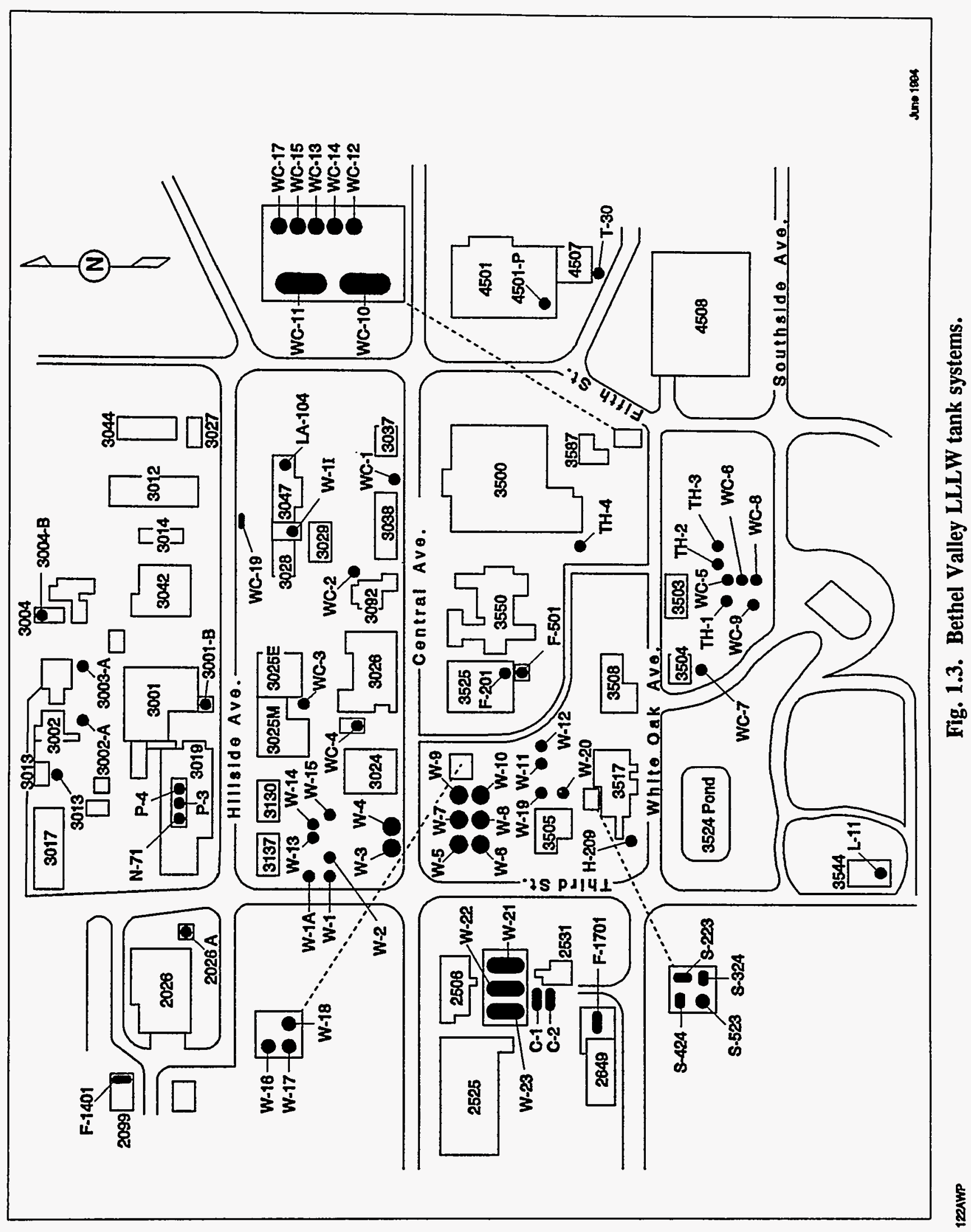




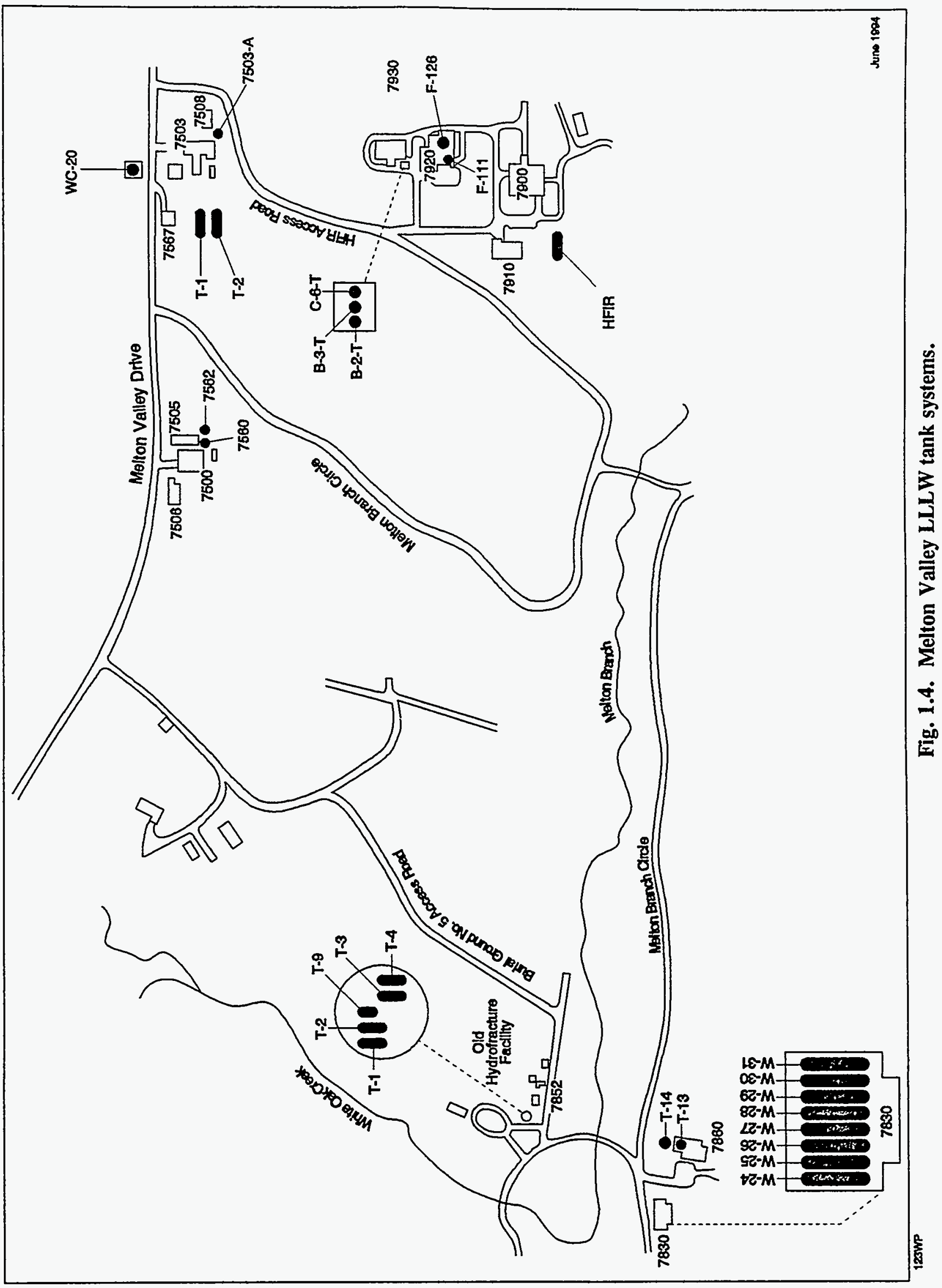




\section{CATEGORY A TANK SYSTEMS}

\subsection{FFA DELIVERABLE}

The FFA requires DOE to prepare design assessments demonstrating that new or replacement tank systems meet the standards for design, containment, and release detection specified in FFA Appendix F, Sects. B and C. This chapter contains the schedules by which these assessments are being conducted and indicates the dates for submittal of information to EPA/TDEC. Design assessments will be submitted to EPA and TDEC for approval at least 90 days prior to start of construction. An installation assessment will be performed at the end of the project to document changes to the system, and the assessment will be on file.

\subsection{STATUS}

Design assessments are being prepared for projects that install, upgrade, and/or replace deficient LLLW systems at ORNL. The first assessment was submitted for the general plant project FFA Compliance, Building 3019A, ${ }^{1}$ which upgrades the LLLW system for Bldg. 3019A by installing a new doubly contained discharge line and a new valve box to tie the new line into the existing discharge line from the facility. The second assessment covered the upgrades to take place in the Melton Valley LLLW Collection and Transfer System line item project. ${ }^{2}$ This line item project installs new LLLW discharge lines from the Radiochemical Engineering Development Center (REDC) and a Monitoring and Control Station (MCS) with a local collection tank, and replaces the existing LLLW transfer line that runs between Melton and Bethel Valleys. Line item project Bethel Valley LLW-CAT System Upgrade installed an MCS with a local collection tank to serve buildings 2026 and an MCS equivalent in the new Transferred Waste Receiving Facility (TWRF). Phase II of the line item project will install an MCS to serve Bldgs. 3525 and 3025 . The Bethel Valley FFA Upgrade line item project will connect Bldg. 3025 to this MCS. Line item project Melton Valley Storage Tank Capacity Increase will install new tanks to increase the storage capacity for concentrates from the central LLLW evaporator. The schedule for installing Category A systems is shown in Table 2.1.

Future design assessments will be submitted at least 90 days prior to the start of project construction. The current schedule for submitting these documents is shown in Fig. 2.1.

- The schedules presented in this section are subject to annual renegotiation to adjust for updated information based on duration of activities or for changes in priorities and funding. 
Table 2.1. Projects that will install Category A tank systems

\begin{tabular}{|c|c|c|c|c|c|}
\hline $\begin{array}{l}\text { Year of } \\
\text { funding } \\
(\mathrm{FY})\end{array}$ & $\begin{array}{l}\text { Projected } \\
\text { completion } \\
\text { date (FY) }\end{array}$ & $\begin{array}{l}\text { Project } \\
\text { title }\end{array}$ & $\begin{array}{l}\text { Project } \\
\text { scope }\end{array}$ & $\begin{array}{c}\text { Tank } \\
\text { system }\end{array}$ & $\begin{array}{l}\text { Type of } \\
\text { funding }\end{array}$ \\
\hline 1992 & 1996 & $\begin{array}{l}\text { Melton } \\
\text { Valley } \\
\text { LLLW-CAT } \\
\text { System } \\
\text { Upgrade }\end{array}$ & $\begin{array}{l}\text { Deletes, } \\
\text { replaces or } \\
\text { upgrades } \\
\text { tank systems } \\
\text { for REDC } \\
\text { and HFIR }\end{array}$ & $\begin{array}{l}\text { Installs MCS } \\
\text { with local } \\
\text { collection tank }\end{array}$ & $\begin{array}{c}\text { line item } \\
\text { project }\end{array}$ \\
\hline 1988 & 1994 & $\begin{array}{l}\text { Bethel Valley } \\
\text { LLLW-CAT } \\
\text { System } \\
\text { Upgrade } \\
\text { Phase I }\end{array}$ & $\begin{array}{l}\text { Deletes, } \\
\text { replaces or } \\
\text { upgrades } \\
\text { LLW-CAT } \\
\text { system for } \\
\text { Bldg. } 2026\end{array}$ & $\begin{array}{l}\text { Installs MCS } \\
\text { with local } \\
\text { collection } \\
\text { tank. Installs } \\
\text { MCS equiv- } \\
\text { alent in Bldg. } \\
2649 .\end{array}$ & $\begin{array}{c}\text { line item } \\
\text { project }\end{array}$ \\
\hline 1988 & 1997 & $\begin{array}{l}\text { Bethel Valley } \\
\text { LLW-CAT } \\
\text { System } \\
\text { Upgrade } \\
\text { Phase II }\end{array}$ & $\begin{array}{l}\text { Deletes, } \\
\text { replaces or } \\
\text { upgrades } \\
\text { LLW-CAT } \\
\text { systems for } \\
\text { Bldgs. 3092, } \\
\text { and } 3525\end{array}$ & $\begin{array}{l}\text { Installs MCS } \\
\text { with local } \\
\text { collection tank }\end{array}$ & $\begin{array}{c}\text { line item } \\
\text { project }\end{array}$ \\
\hline 1994 & 1998 & $\begin{array}{l}\text { Bethel Valley } \\
\text { FFA } \\
\text { Upgrades }\end{array}$ & $\begin{array}{l}\text { Deletes, } \\
\text { replaces or } \\
\text { upgrades } \\
\text { tank systems } \\
\text { for Bldg. } \\
3503,3025 \\
\text { and } 2533 \text {. }\end{array}$ & $\begin{array}{c}\text { Installs } \\
\text { replacement } \\
\text { transfer piping }\end{array}$ & $\begin{array}{c}\text { line item } \\
\text { project }\end{array}$ \\
\hline 1994 & 1998 & $\begin{array}{l}\text { Melton } \\
\text { Valley } \\
\text { Storage Tank } \\
\text { Capacity } \\
\text { Increase }\end{array}$ & $\begin{array}{l}\text { Provides } \\
\text { additional } \\
\text { storage } \\
\text { capacity for } \\
\text { LLLW } \\
\text { concentrates }\end{array}$ & $\begin{array}{c}\text { Installs } \\
\text { additional } \\
\text { concentrate } \\
\text { storage tanks }\end{array}$ & $\begin{array}{c}\text { line item } \\
\text { project }\end{array}$ \\
\hline
\end{tabular}

Note: Based on FY 1996 Activity Data Sheets (ADS), target funding levels. 


\begin{tabular}{l} 
DESIGN ASSESSMENTS FOR \\
CATEGORY A (NEW OR REPLACEMENT) TANK SYSTEMS \\
\hline \multicolumn{1}{|c|}{ ACTITY } \\
\hline
\end{tabular}




\section{REFERENCES FOR CHAPTER 2}

1. Design Assessment for Federal Facility Agreement Compliance Work, Building 3019A Liquid Low-Level Waste Tank Systems at Oak Ridge National Laboratory, Oak Ridge, Tennessee (DOE/OR/03-1097\&D1), Ebasco, Oak Ridge, Tennessee, January 1994.

2. Design Assessment for Melton Valley Liquid Low-Level Waste Collection and Transfer System at Oak Ridge National Laboratory, Oak Ridge, Tennessee (DOE/OR/031258\&D1), Enserch Environmental Corp., Oak Ridge, Tennessee, May 1994. 


\section{CATEGORY B TANK SYSTEMS}

\subsection{FFA DELIVERABLE}

The FFA requires the DOE to demonstrate that the secondary containments for Category B tank systems meet the design and operating conditions specified in FFA Appendix F, Sect. C.

\subsection{STATUS}

Design demonstrations have been submitted for all Category B tanks ${ }^{1,2}$ and pipelines ${ }^{3}$ as shown in Fig. 3.1. The objective of each assessment is to demonstrate that the design of the secondary containment system meets the requirements of the FFA, Appendix F, Sect. C. Twelve tank systems (T-13, W-21, W-22, W-23, W-24, W-25, W-26, W-27, W-28, W-29, W-30, and W-31) meet the requirements of the FFA. Fifteen Tank Systems (N-71, P-3, P-4, C-1, C-2, L-11, B-2-T, B-3-T, C-6-T, F-111, F-126, WC-20, S-223, S-324, and S-523) have minor deficiencies in the tank secondary containment design for which there are one or more mitigating design features. Some of the piping associated with secondarily contained tank systems is singly contained, notably, buried transfer piping connecting the tanks to the central waste collection system. Projects planned or initiated to correct these noted deficiencies are summarized in Table 3.1; the schedule for these upgrades is shown in Table 3.2. Until the projects correcting these pipeline deficiencies are completed, the pipelines will be periodically leak tested. ${ }^{4}$

Additionally, three tank systems originally considered as Category B (F-201, F-501, and LA-104) do not fully meet the secondary containment requirements and will not be upgraded. Two of these systems (F-201 and F-501) have been transferred to Category C and will be subject to the FFA requirements for Category $C$ until they are removed from service upon completion of the Bethel Valley LLLW Collection and Transfer System Upgrade Project. Tank system LA-104 has been transferred to Category D. 


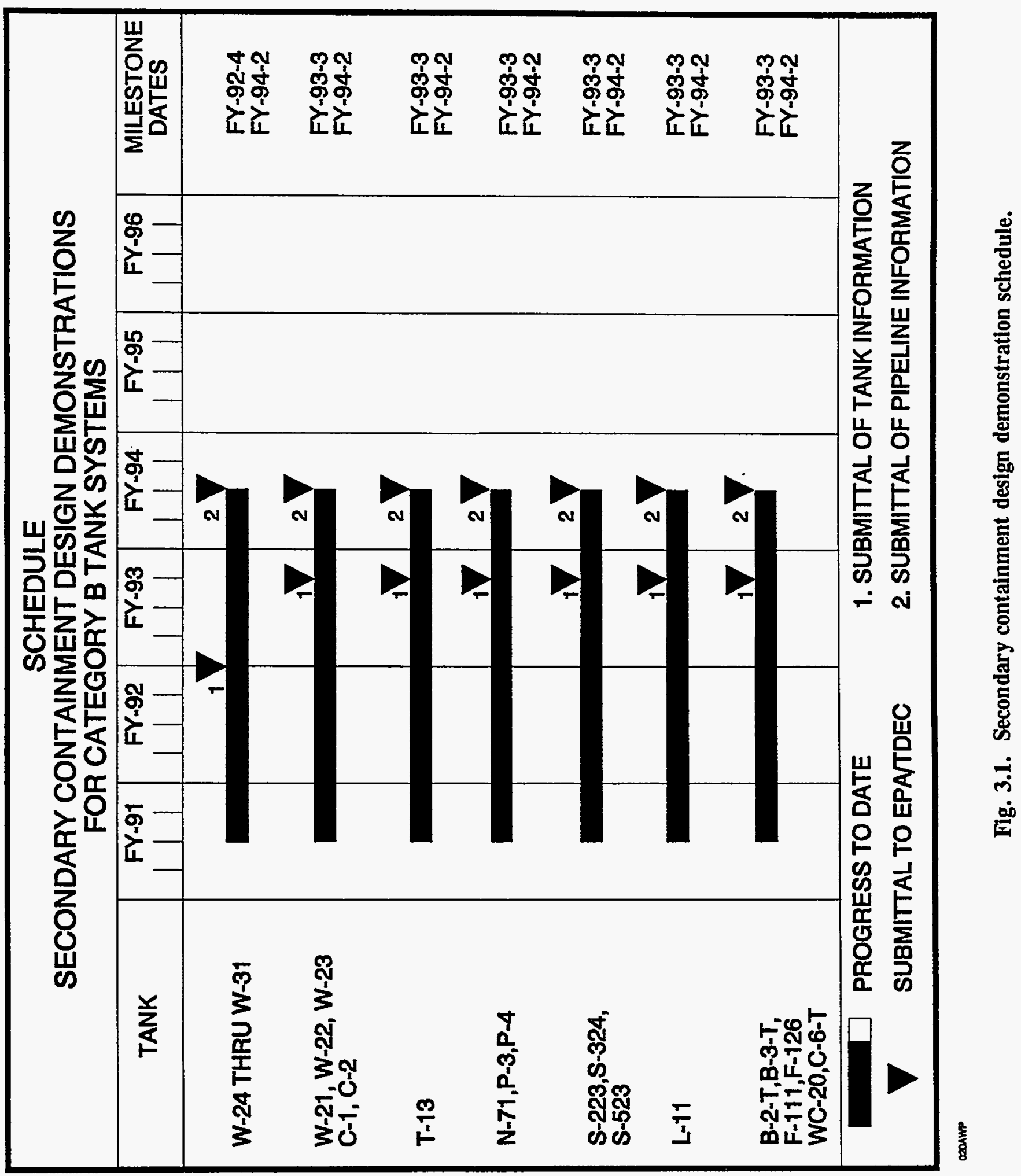


Table 3.1. Projects for upgrading/replacing Category B LLLW tank systems

\begin{tabular}{|c|c|c|c|c|c|}
\hline $\begin{array}{l}\text { Year of } \\
\text { funding } \\
\text { (FY) }\end{array}$ & $\begin{array}{l}\text { Projected } \\
\text { completion } \\
\text { date (FY) }\end{array}$ & $\begin{array}{l}\text { Project } \\
\text { title }\end{array}$ & $\begin{array}{l}\text { Project } \\
\text { scope }\end{array}$ & $\begin{array}{c}\text { Tank } \\
\text { system }\end{array}$ & $\begin{array}{l}\text { Type of } \\
\text { funding }\end{array}$ \\
\hline 1993 & 1995 & 7930 Filter Pit Cover & Encloses filter pit at REDC & & GPP \\
\hline 1994 & 1995 & NHF Cell Plugs Enclosures & $\begin{array}{l}\text { Eliminates non- } \\
\text { programmatic waste } \\
\text { generation at } 7830 \text { and } \\
7860\end{array}$ & & GPP \\
\hline 1994 & 1995 & $\begin{array}{l}\text { Incinerator Drive/OHF } \\
\text { Valve Box Upgrade }\end{array}$ & $\begin{array}{l}\text { Upgrades valve boxes to } \\
\text { meet FFA requirements }\end{array}$ & $\begin{array}{l}\text { Melton } \\
\text { Valley } \\
\text { Facilities }\end{array}$ & GPP \\
\hline 1992 & 1996 & $\begin{array}{l}\text { FFA Compliance Work, } \\
\text { Bldg. 3019A }\end{array}$ & $\begin{array}{l}\text { Doubly contains piping for } \\
3019\end{array}$ & $\begin{array}{l}\text { N-71, } \\
\text { P-3, P-4 }\end{array}$ & GPP \\
\hline 1995 & 1997 & W-6 Valve Box Upgrade & $\begin{array}{l}\text { Upgrades valve box to meet } \\
\text { FFA requirements }\end{array}$ & & GPP \\
\hline 1995 & 1997 & $\begin{array}{l}\text { East Evaporator Valve Pit } \\
\text { Upgrade }\end{array}$ & $\begin{array}{l}\text { Upgrades valve pit to meet } \\
\text { FFA requirements }\end{array}$ & & GPP \\
\hline 1996 & 2000 & $\begin{array}{l}\text { ORNL Process } \\
\text { Waste } \\
\text { Treatment } \\
\text { Facility }\end{array}$ & $\begin{array}{l}\text { Eliminates generation of } \\
\text { LLLW by process waste } \\
\text { treatment operations }\end{array}$ & L-11 & $\begin{array}{l}\text { line item } \\
\text { project }\end{array}$ \\
\hline 1992 & 1996 & $\begin{array}{l}\text { Melton Valley LLLW-CAT } \\
\text { System Upgrade }\end{array}$ & $\begin{array}{l}\text { Deletes, replaces or } \\
\text { upgrades tank systems for } \\
\text { REDC and HFIR }\end{array}$ & $\begin{array}{c}\text { B-2-T, } \\
\text { B-3-T, } \\
\text { C-6-T } \\
\text { F-111, } \\
\text { F-126, } \\
\text { WC-20 } \\
\text { HFIR } \\
\text { T-12 } \\
\text { T-2 }\end{array}$ & $\begin{array}{l}\text { line item } \\
\text { project }\end{array}$ \\
\hline 1994 & 1994 & Bldg. 3517 LLLW Upgrade & $\begin{array}{l}\text { Installs valve inside bldg. to } \\
\text { allow leak testing of } \\
\text { discharge line }\end{array}$ & $\begin{array}{l}\text { S-223 } \\
\text { S-523 } \\
\text { S-324 }\end{array}$ & Expense \\
\hline
\end{tabular}

Note: Based on FY 1996 Activity Data Sheets (ADS), target funding levels.

"Category $\mathrm{C}$ tanks that are included in the line item project. These tanks will be removed from service within 1 year after project completion.

Table 3.2. Schedule for upgrade of of Category B tank systems

\begin{tabular}{|c|c|c|}
\hline Fiscal year & $\begin{array}{l}\text { Tank systems } \\
\text { upgraded }\end{array}$ & 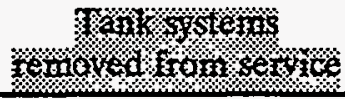 \\
\hline 1996 & $\begin{array}{c}\text { P-3, P-4, N-71, B-2-T, } \\
\text { B-3-T, C-6-T, F-111, F-126 }\end{array}$ & \\
\hline 9999 & & 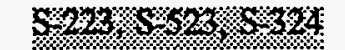 \\
\hline 99 & & 16 \\
\hline 2001 & & 的原 \\
\hline
\end{tabular}




\section{REFERENCES FOR CHAPTER 3}

1. Design Demonstrations for Category B Tank Systems at Oak Ridge National Laboratory, Oak Ridge, Tennessee, DOE/OR-1047 \& D1, Ebasco, Oak Ridge, Tennessee, May 1993.

2. Design Demonstration for the Remaining 19 Category B Tank Systems at Oak Ridge National Laboratory, Oak Ridge, Tennessee, DOE/OR/03-1150 \& D1, Ebasco, Oak Ridge, Tennessee, June 1993.

3. Design Demonstrations for Category B Tank System Piping at Oak Ridge National Laboratory, Oak Ridge, Tennessee, DOE/OR/03-1195\&D1, Ebasco, Oak Ridge, Tennessee, February 1993.

4. Dennis G. Douglas et al., Detailed Leak Detection Test Plan and Schedule for the Oak Ridge National Laboratory LLLW Active Pipelines, DOE/OR/01-1167\&D2, Martin Marietta Energy Systems, Inc., Oak Ridge, Tennessee, /4ngust $99 \%$. 


\section{CATEGORY C TANK SYSTEMS}

\subsection{BACKGROUND}

The FFA allows tank systems that do not meet secondary containment standards to remain in service until the system can be upgraded or replaced, as long as the tank systems are not leaking and no adverse change occurs in the tank systems' baseline structural integrity data. If a tank system leaks, all programmatic inputs will be stopped, provided that complete shutdown of the tank system would not pose unacceptable environmental, health, or safety risk (e.g., reactor cooling-water treatment systems). Such systems will be repaired or replaced as soon as practicable.

\subsection{FFA DELIVERABLE}

\subsubsection{Removal from Service}

The FFA requires DOE to remove from service any tanks that do not meet the secondary containment standards in FFA Appendix F, Subsect. C. The updated plan and schedule for removing Category $\mathrm{C}$ tank systems from service is shown in Table 4.1.

\subsubsection{Status}

General plant projects (GPPs) and line item projects are being planned and implemented to upgrade or replace the LLLW tank systems that do not meet secondary containment and leak detection standards (Category C). The schedule for expense-funded projects for FFA early actions for singly contained LLLW tank systems is shown in Table 4.2; the schedule for capital projects is shown in Table 4.3.

The schedules presented in this section will continue to be subject to annual renegotiation to adjust for updated information based on duration of activities or for changes in priorities and funding.

\subsubsection{Structural Integrity Assessment}

The FFA requires DOE to provide information concerning the structural integrity of tank systems not meeting the secondary containment standards (Category $\mathrm{C}$ ).

\subsubsection{Status}

The information to be submitted will follow the requirements of FFA Appendix F, Subsect. A., titled "Standards for Integrity Assessment for Tank System(s)." The structural integrity assessments (SIAs) will include tank system design data, generic descriptions of the hazardous or radioactive contents, a description of the system's corrosion protection measures, the age of the tank system, and the results of leak tests on the tank system. 
Table 4.1. Projects for modifying FFA singly contained LLLW tank systems

\begin{tabular}{|c|c|c|c|c|c|c|}
\hline Tank location & Tank system & Project title & Project scope & $\begin{array}{c}\text { Funding } \\
\text { (FY and type) }\end{array}$ & $\begin{array}{l}\text { Projected } \\
\text { completion } \\
\text { date (FY) }\end{array}$ & $\begin{array}{c}\text { Removal from } \\
\text { service } \\
\text { to }\end{array}$ \\
\hline \multirow{2}{*}{$\begin{array}{l}\text { Isotopes } \\
\text { Circle } \\
\text { Facilities }\end{array}$} & WC-10 & $\begin{array}{l}\text { Isotope facility } \\
\text { shutdown }\end{array}$ & $\begin{array}{l}\text { Removes WC-10 from } \\
\text { service }\end{array}$ & Expense & 1998 & 1998 \\
\hline & WC-2 & $\begin{array}{l}\text { Isotope facility } \\
\text { shutdown }\end{array}$ & Removes WC-2 from service & Expense & 1996 & 1996 \\
\hline HFIR & $\begin{array}{l}\text { HFIR } \\
\text { T-1 } \\
\text { T-2 }\end{array}$ & $\begin{array}{l}\text { Melton Valley } \\
\text { LLLW-CAT } \\
\text { System Upgrade }\end{array}$ & $\begin{array}{l}\text { Provides an ion exchange } \\
\text { treatment system to convert } \\
\text { LLLW to solid waste and } \\
\text { installs an MCS to eliminate } \\
\text { the need for the tanks }\end{array}$ & FY 92-LIP & 1996 & 1997 \\
\hline BSR/ORR & WC-19 & $\begin{array}{l}\text { BSR/ORR LLLW } \\
\text { Upgrade }\end{array}$ & $\begin{array}{l}\text { Diverts waste from LLLW } \\
\text { system to process waste. }\end{array}$ & FY 92-GPP & 1995 & 1996 \\
\hline \multirow[t]{2}{*}{3025} & WC-3 & $\begin{array}{l}\text { Bethel Valley } \\
\text { FFA Upgrades }\end{array}$ & Replaces WC-3 & FY 94-LIP & 1998 & 1999 \\
\hline & WC-7 & $\begin{array}{l}\text { Bethel Valley } \\
\text { FFA Upgrades }\end{array}$ & $\begin{array}{l}\text { Doubly contains LLLW } \\
\text { piping for } 2533 / 2534 \text { transfer } \\
\text { line }\end{array}$ & FY94-LIP & $\begin{array}{c}1998 \\
\text { (piping) }\end{array}$ & 1999 \\
\hline $\begin{array}{l}\text { Radioactive } \\
\text { (hot) Off Gas }\end{array}$ & WC-9 & $\begin{array}{l}\text { Bethel Valley } \\
\text { FFA Upgrades }\end{array}$ & $\begin{array}{l}\text { Replaces need for WC-9 } \\
\text { Tank System }\end{array}$ & FY 94-LIP & 1998 & 1999 \\
\hline 2026 & $2026 A$ & $\begin{array}{l}\text { Bethel Valley } \\
\text { LLLW-CAT } \\
\text { System Upgrades }\end{array}$ & $\begin{array}{l}\text { Upgrades High Rad Level } \\
\text { Analytical Lab (Bldg. 2026) } \\
\text { LLW-CAT system }\end{array}$ & FY 88-LIP & 1994 & 1995 \\
\hline $3026 \mathrm{D}$ & W-16 & $\begin{array}{l}\text { Isotope Facilities } \\
\text { Shutdown }\end{array}$ & Removes W-16 from service & Expense & 1998 & 1998 \\
\hline
\end{tabular}


Table 4.1. (concluded)

\begin{tabular}{|c|c|c|c|c|c|c|}
\hline Tank location & Tank system & Project title & Project scope & $\begin{array}{c}\text { Funding } \\
\text { (FY and type) }\end{array}$ & $\begin{array}{c}\text { Projected } \\
\text { completion } \\
\text { date (FY) }\end{array}$ & 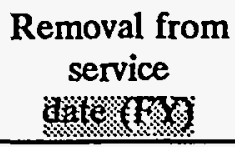 \\
\hline $\begin{array}{l}\text { Radioactive } \\
\text { (hot) Off Gas }\end{array}$ & WC-9 & $\begin{array}{l}\text { Upgrade WC-9 } \\
\text { Transfer System }\end{array}$ & $\begin{array}{l}\text { Bypasses leaking pump in } \\
\text { pump pit }\end{array}$ & Expense & 1994 & NA \\
\hline 3525 & $\begin{array}{l}\text { F-201 } \\
\text { F-501 }\end{array}$ & $\begin{array}{l}\text { Bethel Valley } \\
\text { LLLW-Cat } \\
\text { System Upgrades }\end{array}$ & $\begin{array}{l}\text { Upgrades High Rad Level } \\
\text { Examination Lab (Bldg. } \\
\text { 3525) LLW-CAT system }\end{array}$ & FY 88-LIP & 1997 & 1998 \\
\hline
\end{tabular}


Table 4.2. Treatment projects for newly generated LLLW

\begin{tabular}{|c|c|c|c|}
\hline $\begin{array}{l}\text { Funding } \\
\text { year }\end{array}$ & Title & Scope & $\begin{array}{l}\text { Locations of } \\
\text { interim } \\
\text { upgrades }^{a}\end{array}$ \\
\hline 1990 & $\begin{array}{l}4501 \text { Source } \\
\text { Treatment }\end{array}$ & $\begin{array}{l}\text { Installs source treatment to reduce } \\
\text { radioactivity of } L L L W \text { to meet bottling } \\
\text { requirements }\end{array}$ & 4501 \\
\hline $1990-94$ & $\begin{array}{l}\text { HFIR Source } \\
\text { Treatment }\end{array}$ & $\begin{array}{l}\text { Installs source treatment to reduce } \\
\text { volume and radioactivity of LLLW }\end{array}$ & HFIR \\
\hline $1990-94$ & $\begin{array}{l}\text { REDC Source } \\
\text { Treatment }\end{array}$ & $\begin{array}{l}\text { Installs source treatment to reduce } \\
\text { volume of LLLW; installs temporary } \\
\text { trucking station }\end{array}$ & REDC \\
\hline $1992-93$ & $\begin{array}{l}3517 \text { Source } \\
\text { Treatment }\end{array}$ & $\begin{array}{l}\text { Upgrades filter pit sump to reduce } \\
\text { nonprogrammatic waste inputs }\end{array}$ & 3517 \\
\hline $1993-94$ & $\begin{array}{l}3025 \text { Source } \\
\text { Treatment }\end{array}$ & $\begin{array}{l}\text { Installs source treatment to remove }{ }^{60} \mathrm{Co} \\
\text { to allow trucking }\end{array}$ & 3025 \\
\hline 1994 & $\begin{array}{c}\text { Pretreatment } \\
\text { REDC LLLW-GPP }\end{array}$ & $\begin{array}{l}\text { Provides capability to remove TRU } \\
\text { constituents from process materials } \\
\text { before discharge to LLLW system }\end{array}$ & REDC \\
\hline
\end{tabular}

Note: Based on FY 1996 Activity Data Sheets (ADS), target funding level.

"See Fig. 1.2 for LLLW tank systems associated with a given facility. 
Table 4.3. Capital projects for FFA early actions for singly contained LLLW tank systems

\begin{tabular}{|c|c|c|c|c|}
\hline $\begin{array}{l}\text { Funding } \\
\text { year }\end{array}$ & $\begin{array}{l}\text { Completion } \\
\text { year }\end{array}$ & Title & Scope & $\begin{array}{c}\text { Tank } \\
\text { locations }\end{array}$ \\
\hline 1992 & 1995 & $\begin{array}{c}\text { BSR/ORR } \\
\text { LLLW Upgrade }\end{array}$ & $\begin{array}{l}\text { Diverts waste from LLLW } \\
\text { system to process waste }\end{array}$ & ORR/BSR \\
\hline 1993 & 1995 & $\begin{array}{l}3108 \text { Filter Pit } \\
\text { Enclosure }\end{array}$ & $\begin{array}{l}\text { Encloses filter pit } 3108 \text { that } \\
\text { serves Building } 3019\end{array}$ & 3019 \\
\hline 1996 & 1998 & $\begin{array}{l}1 \text { GPP to be } \\
\text { defined }\end{array}$ & $\begin{array}{l}\text { Eliminates nonprogrammatic } \\
\text { waste generation or upgrades } \\
\text { appropriate } \\
\text { collection/transport system }\end{array}$ & \\
\hline 1997 & 1999 & $\begin{array}{l}1 \text { GPP to be } \\
\text { defined }\end{array}$ & $\begin{array}{l}\text { Eliminates nonprogrammatic } \\
\text { waste generation or upgrades } \\
\text { appropriate } \\
\text { collection/transport system }\end{array}$ & \\
\hline 1998 & 2001 & $\begin{array}{l}1 \text { GPP to be } \\
\text { defined }\end{array}$ & $\begin{array}{l}\text { Eliminates nonprogrammatic } \\
\text { waste generation or upgrades } \\
\text { appropriate } \\
\text { collection/transport system }\end{array}$ & \\
\hline
\end{tabular}

Note: Based on FY 1996 Activity Data Sheets (ADS), target funding levels.

see Fig. 1.2 for LLLW tanks associated with a given facility. 
The structural integrity assessments for the tank systems not meeting secondary containment standards will be submitted in accordance with the schedule in Fig. 4.1. The schedule extension beyond the initial submittal of SIAs, as shown in Fig. 4.1, indicates the periodic review of SIAs. The results of the periodic reviews will be submitted to EPA/TDEC. They will consist of the results of leak tests and notice of any change in the baseline design data provided in the SIA.

The schedules presented in this section will be subject to annual renegotiation to adjust for updated information based on duration of activities or for changes in priorities and funding.

\subsubsection{Leak Detection Tests}

The FFA requires DOE to provide the schedule for periodic review and revision of the structural integrity assessments and to provide leak detection test results for Category $\mathrm{C}$ tank systems. These schedules are updated in Figs. 4.1 and 4.2 respectively.

\subsubsection{Status}

The Category $\mathrm{C}$ tank systems will be leak tested. The Category $\mathrm{B}$ tanks that demonstrated secondary containment in accordance with FFA requirements have been removed from the Leak Testing Program. The pipelines for several Category B Tank Systems will be included in the Leak Testing Program on the basis of results from the Secondary Containment Design Demonstration documents., 4,5 The schedule for initial leak testing of the tanks ${ }^{1}$ is shown in Table 4.4. Initial pipeline testing for Category $\mathrm{C}$ systems as well as for the required (singly contained) parts of the Category B systems was initiated

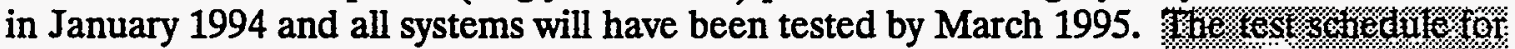

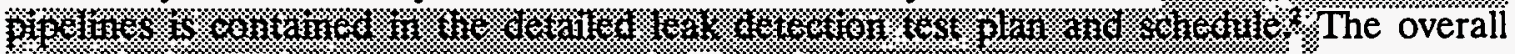
schedule for FFA submittals is shown in Fig. 4.2.

Table 4.4. Schedule for initiating leak testing of tanks

\begin{tabular}{c|c|c|c|c}
\hline JUN 1993 & SEP 1993 & DEC 1993 & MAR 1994 & MAR 1995 \\
\hline WC-3 & W-16 & T-1 & 2026A & HFIR \\
WC-7 & WC-10 & T-2 & F-201 & \\
WC-9 & & W-12 & F-501 & \\
& & WC-2 & & \\
& & WC-19 & & \\
\hline
\end{tabular}

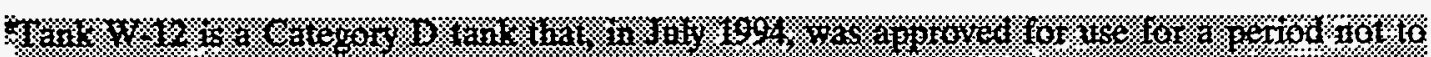

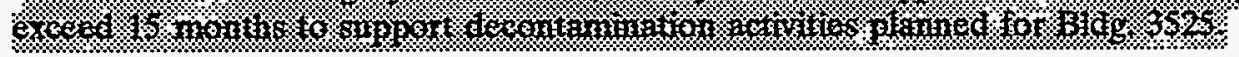




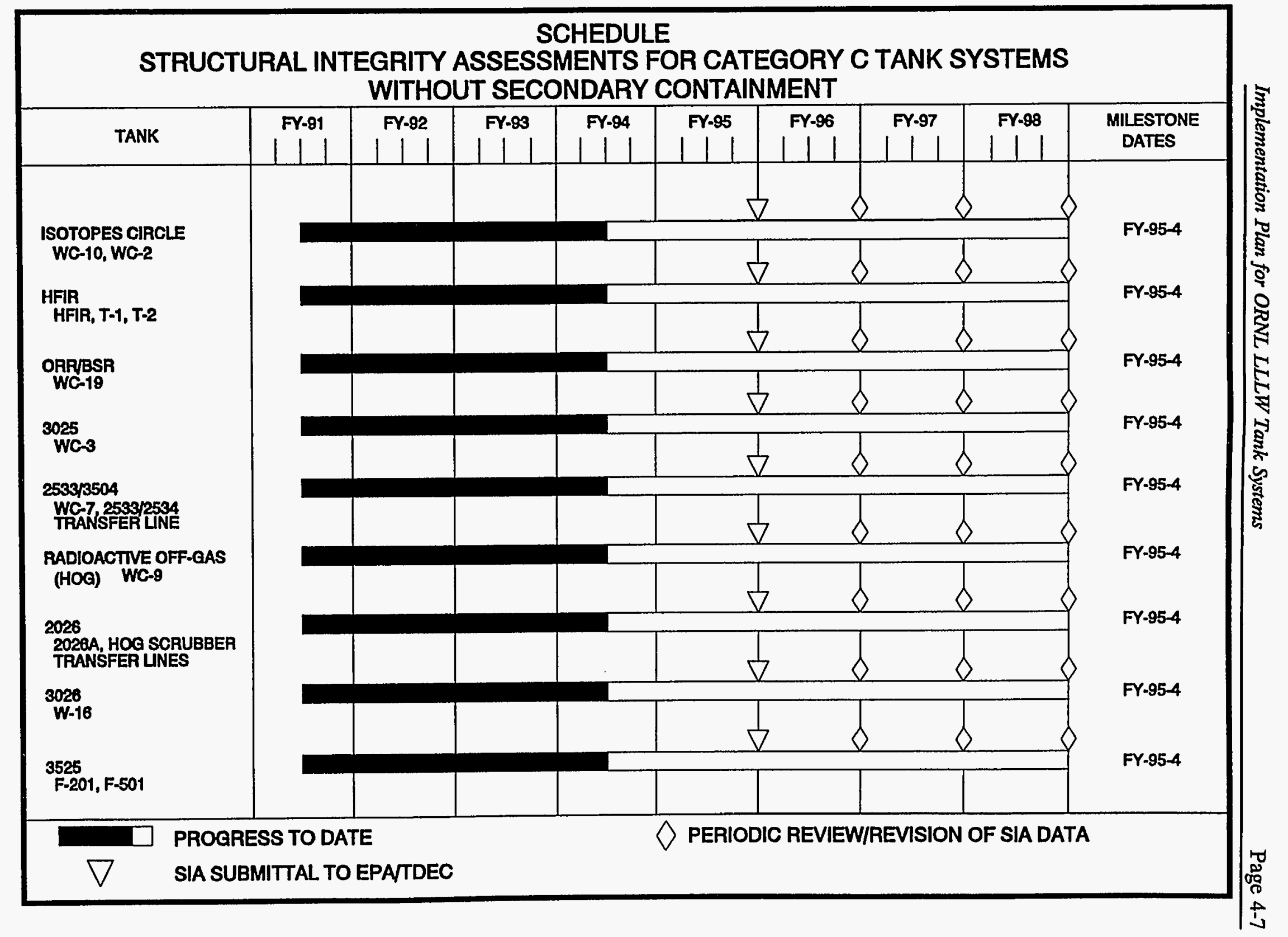

Fig. 4.1. Structural integrity assessments schedule for tank systems not meeting secondary containment standards. 


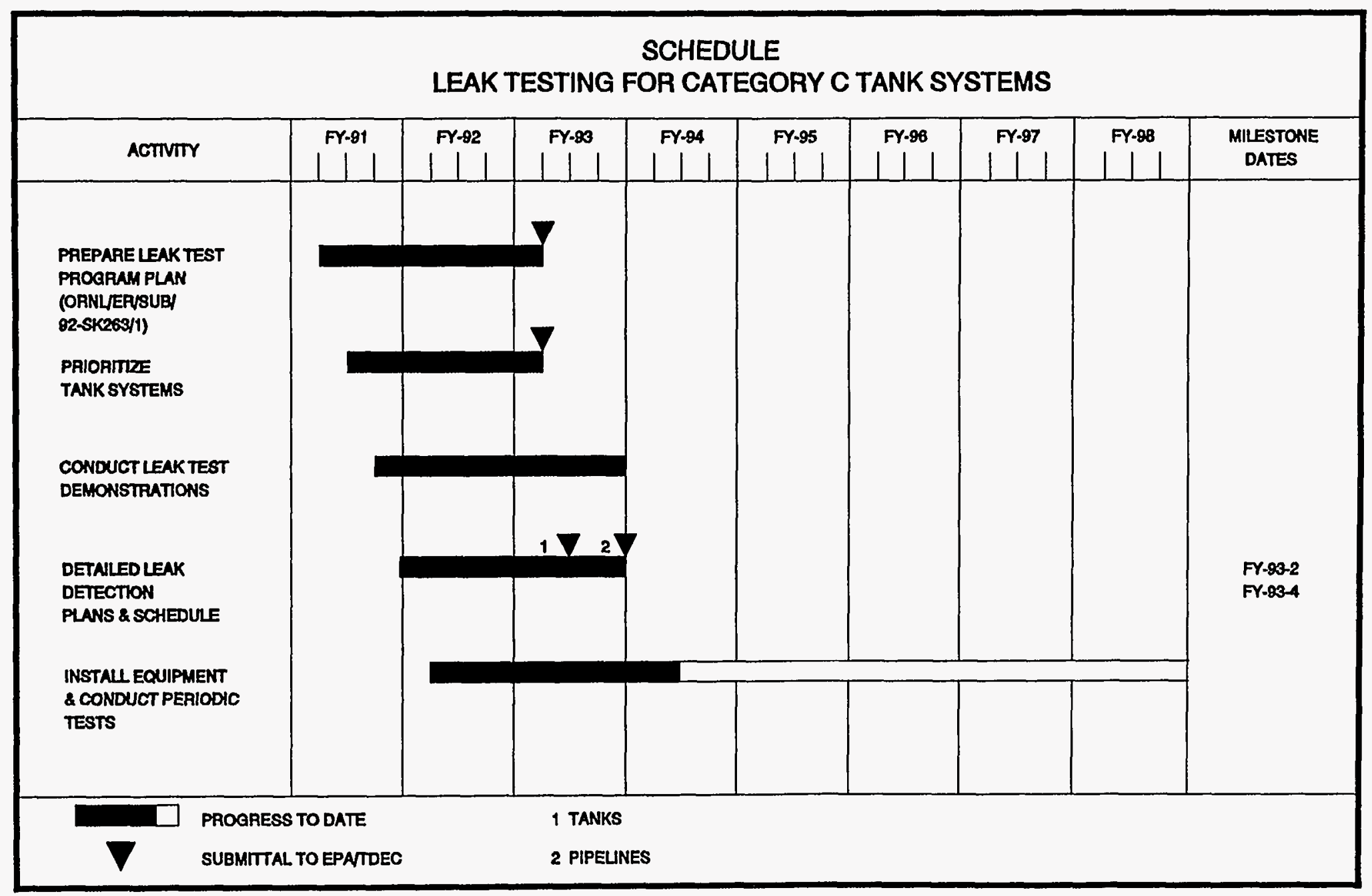

Fig. 4.2. Leak testing schedule for Category $\mathrm{C}$ tank systems. 


\section{REFERENCES FOR CHAPTER 4}

1. Dennis G. Douglas and Joseph W. Maresca, Jr., Detailed Leak Detection Test Plan and Schedule for the Oak Ridge National Laboratory LLLW Active Tanks, DOE/OR/011129\&D1 ORNL/ER/Sub/92-SK263/2\&D1, Martin Marietta Energy Systems, Inc., Oak Ridge, Tennessee, March 1993.

2. Dennis G. Douglas et al., Detailed Leak Detection Test Plan and Schedule for the Oak Ridge National Laboratory LLLW Active Pipelines, DOE/OR/01-1167\&/2, Martin Marietta Energy Systems, Inc., Oak Ridge, Tennessee, \%ugusf

3. Design Demonstrations for Category B Tank Systems at Oak Ridge National Laboratory, Oak Ridge, Tennessee DOE/OR-1047 \& D1, Ebasco, Oak Ridge, Tennessee, May 1993.

4. Design Demonstration for the Remaining 19 Category B Tank Systems at Oak Ridge National Laboratory, Oak Ridge, Tennessee DOE/OR/03-1150 \& D1, Ebasco, Oak Ridge, Tennessee, June 1993.

5. Design Demonstrations for Category B Tank System Piping at Oak Ridge National Laboratory, Oak Ridge, Tennessee DOE/OR/03-1195\&D1, Ebasco, Oak Ridge, Tennessee, February 1993. 


\section{CATEGORY D TANK SYSTEMS}

\subsection{WASTE CHARACTERIZATION SCHEDULE FOR THE CATEGORY D TANK SYSTEMS}

Waste characterization data for the tank systems have been submitted to EPA/TDEC. ${ }^{1}$ Tanks that have been emptied so that only a very small residue remains will not be characterized. Data will be provided for additional tank systems as they are removed from service.

\subsection{RISK CHARACTERIZATION SCHEDULE FOR THE CATEGORY D TANK SYSTEMS}

Risk characterization data has been submitted to EPA/TDEC. ${ }^{2}$ An update to the risk characterization to include future Category $\mathrm{D}$ tanks will be prepared as waste characterization data for these tanks become available.

\subsection{REMEDIATION SCHEDULE FOR THE CATEGORY D TANK SYSTEMS}

The long-term strategy for the Category D tanks is to remediate individual tanks or tank farms under the CERCLA process as part of the waste area grouping (WAG) in which each

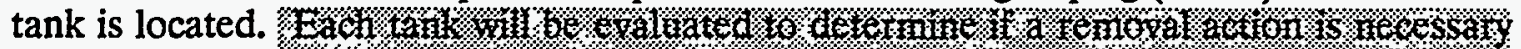

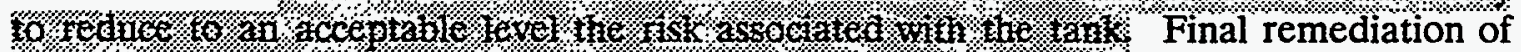
sludge, tank shells, and associated piping will be evaluated during the remedial investigation/feasibilitystudy (RI/FS) for the WAG. A schedule for remediation of Category D tanks was submitted to EPA/TDEC in March 19933. This schedule will be renegotiated annually, if necessary.

\subsection{PROPOSED ACTIVITIES}

This chapter contains the proposed schedules for the Category D LLLW tank systems for which liquid contents will be removed, for which early actions will be evaluated, or for which early actions will be initiated. A remediation schedule submitted in March, 1993 reflected the plans at that time. Information on current status and planned activities for Category $\mathrm{D}$ tanks is contained in Table 5.1.

The proposed schedules presented in this chapter are for proposed activities and are based on the latest information. The implementation and duration of these proposed activities are subject to change due to changes in priority, funding, and resolution of technical issues. 
Table 5.1. Status and planned activities for Category D LLLW tank systems

\begin{tabular}{|c|c|c|c|c|c|c|c|}
\hline \multirow[b]{2}{*}{$\begin{array}{c}\text { Tank } \\
\text { number }\end{array}$} & \multirow[b]{2}{*}{$\begin{array}{l}\text { Capacity } \\
\text { (gal) }\end{array}$} & \multirow{2}{*}{$\begin{array}{l}\text { Actual } \\
\text { volume } \\
\text { (gal) }\end{array}$} & \multicolumn{2}{|c|}{ Curie content } & \multirow{2}{*}{$\begin{array}{l}\text { Schedule to } \\
\text { empty }\end{array}$} & \multirow{2}{*}{$\begin{array}{l}\text { Inleakage/ } \\
\text { outleakage }\end{array}$} & \multirow[b]{2}{*}{ Monitor } \\
\hline & & & Alpha & Beta & & & \\
\hline$\overline{\mathrm{W}-5}$ & 170,000 & 21,805 & 1.0 & $\overline{144.4}$ & GAAT OU & Inleakage & $\overline{\mathrm{CT}^{2}}$ \\
\hline W-6 & 170,000 & 126,190 & 6.32 & 940.0 & GAAT OU & Inleakage & $\overline{C T^{2}}$ \\
\hline W-7 & 170,000 & 3,220 & 11.14 & 2800.0 & GAAT OU & Probably not & $\overline{C T^{2}}$ \\
\hline W-8 & 170,000 & 51,933 & 11.58 & 3410.0 & GAAT OU & Inleakage & $\overline{C T^{2}}$ \\
\hline W-9 & 170,000 & 38,319 & 43.08 & 2094.0 & GAAT OU & $\begin{array}{l}\text { Very slight } \\
\text { inleakage }\end{array}$ & $\mathrm{CT}^{2}$ \\
\hline W-10 & 170,000 & 99,074 & 83.2 & $13,400.0$ & GAAT OU & $\begin{array}{l}\text { Very slight } \\
\text { inleakage }\end{array}$ & $\overline{C T^{2}}$ \\
\hline W-11 & 1500 & Transient & None & None & GAAT OU & $\begin{array}{c}\text { Inleakage } \\
\text { during heavy } \\
\text { rain }\end{array}$ & Staff \\
\hline $\mathrm{TI}$ & 15,000 & 8,479 & 79.24 & 7292.0 & FY 94/95 & No & $\overline{\mathrm{DP}^{\mathrm{b}}}$ \\
\hline$\overline{T 2}$ & 15,000 & 10,544 & 46.24 & 3860.0 & FY 94/95 & No & $\mathrm{DP}^{\mathrm{b}}$ \\
\hline$\overline{T 3}$ & 25,000 & 2,918 & 62.0 & 7859.0 & FY 94/95 & No & $\mathrm{DP}^{\mathrm{b}}$ \\
\hline $\mathrm{T} 4$ & 25,000 & 14,668 & 75.05 & 7600.0 & FY 94/95 & No & $\mathrm{DP}^{\mathrm{b}}$ \\
\hline $\mathrm{T9}$ & 13,000 & 4,981 & 11.09 & 1245.0 & FY 94/95 & No & $\overline{D P^{b}}$ \\
\hline W-1 & 4800 & 1,013 & None & 0.11 & $\begin{array}{c}\text { FY } 94 \\
\text { GAAT OU }\end{array}$ & Inleakage & $\overline{C T^{2}}$ \\
\hline W-2 & 4800 & 1,527 & None & 0.05 & $\begin{array}{c}\text { FY } 94 \\
\text { GAAT OU }\end{array}$ & Inleakage & $\overline{\mathrm{CT}^{2}}$ \\
\hline W-3 & 42,500 & 41,000 & 2.96 & 523.9 & $\begin{array}{c}\text { FY } 94 \\
\text { GAAT OU }\end{array}$ & Inleakage & Staff \\
\hline$\overline{W-4}$ & 42,500 & 25,578 & 4.0 & 194.5 & $\begin{array}{c}\text { FY 94 } \\
\text { GAAT OU }\end{array}$ & Inleakage & Staff \\
\hline W-13 & 2000 & $\begin{array}{l}\text { Empty } \\
\text { Sept. } 92\end{array}$ & 0.40 & 65.0 & $\begin{array}{c}\text { GAAT OU } \\
\text { Empty }\end{array}$ & $\begin{array}{c}\text { No evidence of } \\
\text { leaks }\end{array}$ & Staff \\
\hline W-14 & 2000 & $\begin{array}{l}\text { Empty } \\
\text { Sept. } 92\end{array}$ & 0.22 & 26.0 & $\begin{array}{c}\text { GAAT OU } \\
\text { Empty }\end{array}$ & $\begin{array}{c}\text { No evidence of } \\
\text { leaks }\end{array}$ & Staff \\
\hline W-15 & 2000 & $\begin{array}{l}\text { Empty } \\
\text { Sept. } 92\end{array}$ & None & None & $\begin{array}{c}\text { GAAT OU } \\
\text { Empty }\end{array}$ & No & Staff \\
\hline $\mathrm{W}-1 \mathrm{~A}$ & 4000 & Varies & Transient & Transient & GAAT OU & Inleakage & $\mathrm{DP}^{\mathrm{b}}$ \\
\hline TH-1 & 2500 & $\begin{array}{c}\text { Empty } \\
\text { Sept. } 92\end{array}$ & None & None & Empty & $\begin{array}{c}\text { No evidence of } \\
\text { leaks }\end{array}$ & None $^{c}$ \\
\hline
\end{tabular}


Table 5.1. (continued)

\begin{tabular}{|c|c|c|c|c|c|c|c|}
\hline \multirow[b]{2}{*}{$\begin{array}{c}\text { Tank } \\
\text { number }\end{array}$} & \multirow[b]{2}{*}{$\begin{array}{l}\text { Capacity } \\
\text { (gal) }\end{array}$} & \multirow{2}{*}{$\begin{array}{l}\text { Actual } \\
\text { volume } \\
\text { (gal) }\end{array}$} & \multicolumn{2}{|c|}{ Curie content } & \multirow{2}{*}{$\begin{array}{l}\text { Schedule to } \\
\text { empty }\end{array}$} & \multirow{2}{*}{$\begin{array}{l}\text { Inleakage/ } \\
\text { outleakage }\end{array}$} & \multirow[b]{2}{*}{ Monitor } \\
\hline & & & Alpha & Beta & & & \\
\hline TH-2 & 2400 & $\begin{array}{l}\text { Empty } \\
\text { Sept. } 92\end{array}$ & None & $\overline{\text { None }}$ & Empty & $\begin{array}{c}\text { No evidence of } \\
\text { leaks }\end{array}$ & $\overline{\text { None }^{c}}$ \\
\hline TH-3 & 3300 & $\begin{array}{l}\text { Empty } \\
\text { Sept. } 92\end{array}$ & None & None & Empty & $\begin{array}{c}\text { No evidence of } \\
\text { leaks }\end{array}$ & None $^{\mathrm{e}}$ \\
\hline TH-4 & 14000 & 16,982 & 3.08 & 10.5 & $\begin{array}{l}\text { GAAT OU } \\
\text { FY } 94 \\
\text { Remove } \\
\sim 7,000 \mathrm{gal}\end{array}$ & $\begin{array}{c}\text { Full beyond } \\
\text { capacity since } \\
\text { sampling in } \\
1988\end{array}$ & $\overline{C T^{2}}$ \\
\hline WC-1 & 2150 & $\begin{array}{l}\text { Empty } \\
\text { Sept. } 92\end{array}$ & None & None & Empty & $\begin{array}{l}\text { No (since } \\
\text { March) }\end{array}$ & $\overline{\text { None }^{e}}$ \\
\hline WC-153 & 1000 & 1000 & 0.0001 & 0.002 & $\begin{array}{l}\text { Aug. } 93 \\
\text { Empty }\end{array}$ & $\begin{array}{c}\text { Inleaks } \\
\text { groundwater }\end{array}$ & $\overline{C T^{2}}$ \\
\hline WC-17 & 1000 & 400 & None & None & $\begin{array}{l}\text { Dec. } 92 \\
\text { Empty }\end{array}$ & $\begin{array}{c}\text { Inleaks } \\
\text { groundwater }\end{array}$ & $\overline{\mathrm{DP}^{2}}$ \\
\hline T-30 & 825 & 400 & 0.0004 & 0.001 & $\begin{array}{l}\text { Emptied } \\
\text { Sept. } 93\end{array}$ & No & $\mathrm{DP}^{\mathrm{b}}$ \\
\hline 7560 & 1000 & $\begin{array}{l}\text { Empty } \\
\text { Dec. } 92\end{array}$ & None & None & Empty & $\begin{array}{c}\text { No evidence of } \\
\text { leaks }\end{array}$ & None $e^{c}$ \\
\hline $7562^{e}$ & 12,000 & 12,000 & None & 3.0 & $\begin{array}{c}\text { Tank } \\
\text { Evaluation }\end{array}$ & $\begin{array}{c}\text { Non- } \\
\text { programmatic } \\
\text { waste input }\end{array}$ & $\overline{\mathrm{DP}}$ \\
\hline W-19 & 2250 & $\begin{array}{l}\text { Empty } \\
1988\end{array}$ & None & None & Empty & $\begin{array}{c}\text { Dry when last } \\
\text { inspected }\end{array}$ & None $^{e}$ \\
\hline W-20 & 2250 & $\begin{array}{c}\text { Empty } \\
1988\end{array}$ & None & None & Empty & $\begin{array}{c}\text { Dry when last } \\
\text { inspected }\end{array}$ & None $^{e}$ \\
\hline $\mathrm{H}-209$ & 2500 (est.) & 380 (est.) & None & None & $\begin{array}{l}\text { Emptied } \\
\text { Sept. } 93\end{array}$ & Unknown & None $^{e}$ \\
\hline 3001-B & 75 & Empty & None & None & Empty & $\begin{array}{l}\text { Empty when } \\
\text { last inspected }\end{array}$ & None $^{c}$ \\
\hline $7503-A$ & 11,000 & 1500 (est.) & None & None & Empty & No & None $^{c}$ \\
\hline $3003-A$ & 16,000 & 4000 (est.) & None & 0.25 & $\begin{array}{l}\text { Emptied } \\
\text { Sept. } 93\end{array}$ & Unknown & None $^{c}$ \\
\hline $3004-B$ & 30 & 30 & None & None & $\begin{array}{l}\text { Emptied } \\
\text { Sept. } 93\end{array}$ & Unknown & None $^{c}$ \\
\hline 3013 & 400 & 235 (est.) & None & None & $\begin{array}{l}\text { Emptied } \\
\text { Sept. } 93\end{array}$ & Unknown & None $^{e}$ \\
\hline
\end{tabular}


Table 5.1. (continued)

\begin{tabular}{|c|c|c|c|c|c|c|c|}
\hline \multirow[b]{2}{*}{$\begin{array}{c}\text { Tank } \\
\text { number }\end{array}$} & \multirow[b]{2}{*}{$\begin{array}{l}\text { Capacity } \\
\text { (gal) }\end{array}$} & \multirow{2}{*}{$\begin{array}{c}\text { Actual } \\
\text { volume } \\
\text { (gal) }\end{array}$} & \multicolumn{2}{|c|}{ Curie content } & \multirow{2}{*}{$\begin{array}{l}\text { Schedule to } \\
\text { empty }\end{array}$} & \multirow{2}{*}{$\begin{array}{l}\text { Inleakage/ } \\
\text { outleakage }\end{array}$} & \multirow[b]{2}{*}{ Monitor } \\
\hline & & & Alpha & $\overline{\text { Beta }}$ & & & \\
\hline $3002-A^{f}$ & 1600 & Transient & Transient & Transient & $\begin{array}{c}\text { Tank } \\
\text { evaluation }\end{array}$ & $\begin{array}{c}\text { Non- } \\
\text { programmatic } \\
\text { waste input } \\
\text { (Filter House) }\end{array}$ & None $^{c}$ \\
\hline$T 14^{I}$ & 48500 & $\begin{array}{l}\text { Empty } \\
\text { Sept. } 92\end{array}$ & None & None & Empty & No & None $^{c}$ \\
\hline $4501-P^{\prime}$ & 100 & $\begin{array}{c}\text { Empty } \\
\text { Sept. } 92\end{array}$ & None & None & Empty & No & None $^{c}$ \\
\hline $\mathrm{S}-424^{i}$ & 500 & $\begin{array}{c}\text { Sept. } 92 \\
\text { Empty }\end{array}$ & None & None & Empty & No & None $^{c}$ \\
\hline$W C-4^{f}$ & 1700 & Transient & Transient & Transient & $\begin{array}{c}\text { Tank } \\
\text { evaluation }\end{array}$ & $\begin{array}{l}\text { Very slight } \\
\text { inleakage }\end{array}$ & $\overline{D P^{b}}$ \\
\hline $\mathrm{WC}-5^{i}$ & 1000 & Transient & Transient & Transient & $\begin{array}{c}\text { Tank } \\
\text { evaluation }\end{array}$ & $\begin{array}{c}\text { Non- } \\
\text { programmatic } \\
\text { waste input }\end{array}$ & $\mathrm{DP}^{\mathrm{b}}$ \\
\hline WC- $6^{f}$ & 500 & Transient & Transient & Transient & $\begin{array}{c}\text { Tank } \\
\text { evaluation }\end{array}$ & $\begin{array}{c}\text { Non- } \\
\text { programmatic } \\
\text { waste input }\end{array}$ & $\mathrm{DP}^{\mathrm{b}}$ \\
\hline WC-8f & 1000 & Transient & Transient & Transient & $\begin{array}{c}\text { Tank } \\
\text { evaluation }\end{array}$ & $\begin{array}{c}\text { Non- } \\
\text { programmatic } \\
\text { waste input } \\
\text { (Pump prime } \\
\text { water) }\end{array}$ & $\overline{\mathrm{DP}^{b}}$ \\
\hline$\overline{W-1 I^{f}}$ & 500 & $\begin{array}{l}\text { Empty } \\
\text { Sept. } 92\end{array}$ & None & None & Empty & No & $\mathrm{DP}^{\mathrm{b}}$ \\
\hline$\overline{W-17^{t}}$ & 1000 & Transient & Transient & Transient & $\begin{array}{c}\text { Tank } \\
\text { evaluation }\end{array}$ & $\begin{array}{c}\text { Non- } \\
\text { programmatic } \\
\text { waste input }\end{array}$ & $\overline{\mathrm{DP}}$ \\
\hline W-18 & 1000 & Transient & Transient & Transient & $\begin{array}{c}\text { Tank } \\
\text { evaluation }\end{array}$ & $\begin{array}{c}\text { Non- } \\
\text { programmatic } \\
\text { waste input }\end{array}$ & $\overline{D^{b}}$ \\
\hline WC-11 & 4000 & Transient & Transient & Transient & $\begin{array}{c}\text { Tank } \\
\text { evaluation }\end{array}$ & $\begin{array}{c}\text { Non- } \\
\text { programmatic } \\
\text { waste input } \\
\text { (Filter pit, cell } \\
\text { ventilation } \\
\text { pump) }\end{array}$ & $\mathrm{DP}^{\mathrm{b}}$ \\
\hline
\end{tabular}


Table 5.1. (continued)

\begin{tabular}{|c|c|c|c|c|c|c|c|}
\hline \multirow[b]{2}{*}{$\begin{array}{c}\text { Tank } \\
\text { number }\end{array}$} & \multirow[b]{2}{*}{$\begin{array}{c}\text { Capacity } \\
\text { (gal) }\end{array}$} & \multirow{2}{*}{$\begin{array}{l}\text { Actual } \\
\text { volume } \\
\text { (gal) }\end{array}$} & \multicolumn{2}{|c|}{ Curie content } & \multirow{2}{*}{$\begin{array}{l}\text { Schedule to } \\
\text { empty }\end{array}$} & \multirow{2}{*}{$\begin{array}{l}\text { Inleakage/ } \\
\text { outleakage }\end{array}$} & \multirow[b]{2}{*}{ Monitor } \\
\hline & & & Alpha & Beta & & & \\
\hline WC-12 & 1000 & Transient & Transient & $\overline{\overline{\text { Transient }}}$ & $\begin{array}{c}\text { Tank } \\
\text { evaluation }\end{array}$ & $\begin{array}{c}\text { Non- } \\
\text { programmatic } \\
\text { waste input } \\
\text { (Sump) }\end{array}$ & $\overline{\mathrm{DP}^{\mathrm{b}}}$ \\
\hline WC-13' & 1000 & Transient & Transient & Transient & $\begin{array}{c}\text { Tank } \\
\text { evaluation }\end{array}$ & $\begin{array}{c}\text { Non- } \\
\text { programmatic } \\
\text { waste input } \\
\text { (Floor sump) }\end{array}$ & $\overline{\mathrm{DP}}$ \\
\hline WC-14 & 1000 & Transiènt & Transient & Transient & $\begin{array}{c}\text { Tank } \\
\text { evaluation }\end{array}$ & $\begin{array}{c}\text { Non- } \\
\text { programmatic } \\
\text { waste input }\end{array}$ & $\overline{D P^{b}}$ \\
\hline $\mathrm{W}-12^{\mathrm{l}}$ & 700 & Transient & Transient & Transient & $\begin{array}{c}\text { Tank } \\
\text { evaluation }\end{array}$ & Inleakage & $\overline{D P^{b}}$ \\
\hline
\end{tabular}

'Conductivity tape.

Differential pressure method.

These tanks have been emptied. These tanks have no level monitors, but they are being incorporated into a comprehensive surveillance and maintenance plan that will specify regular inspections of these tanks to monitor for inleakage.

${ }^{d}$ A review of historical data for Tank WC-17 indicated potential outleakage. In December 1992, Tank WC-17 was emptied and rinsed three times. A video inspection of the tank indicated two holes in the bottom of the tank, which allow groundwater to enter the tanks.

Tank 7562 was scheduled to be emptied in FY 1993; however, an unidentified source of input was discovered. An evaluation is under way to identify and stop the input.

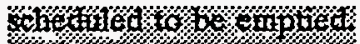

Tout-ol-service tanks that belong to Waste Management (WM). Some of these tanks are receiving nonprogrammatic input, the source of which WM is identifying. After the sources have been identified, a tank-bytank evaluation will be initiated to identify which inputs can be eliminated or diverted. Projects to eliminate inputs were initiated in FY 1993. All tanks were emptied in FY 1993; however, some tanks may have some inleakage or nonprogrammatic inputs that cannot be economically diverted until the facility or area causing the input is remediated.

Tank WC-15 was taken out of service due to leaks. The level monitor indicated a sudden change in the liquid level on August 9,1993. After confirming that the level monitor was functioning properly, the tank was physically accessed and determined to have leaked $\sim 500$ gal. The rest of the contents were pumped out, and a video inspection indicated groundwater was entering at the bottom of the tank. The water level has stabilized at $\sim 40 \%$ of capacity, which is similar to Tank WC-17. 


\subsubsection{Liquid Content Removal Schedule}

The liquid contents in the Old Hydrofracture (OHF) Tanks (T-1, T-2, T-3, T-4, and T-9) will be removed by using the existing piping system if possible. If the existing system cannot be used, a valve box will be built that will bypass the old pumps and tie into the active LLLW system. Some liquid will be left in the tanks to prevent the sludge from drying out.

Tank TH-4 will have approximately 7,000 gal of the liquid contents removed this year. This tank is already in the CERCLA process as part of the Gunite and Associated Tanks Operable Unit (GAAT OU). At present, this tank is full beyond its design capacity. The purpose of partially removing the liquids is to prevent the tank from overfilling and potentially releasing liquid to the environment. Since this tank is not connected to an active LLLW system, the tank will have to be emptied by trucking the liquid to the LLLW system.

Gunite tanks W-1, W-2, W-3, and W-4 will have their liquid contents removed.

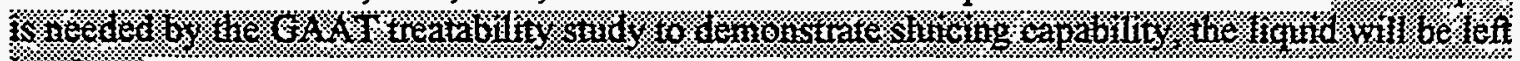
17. II)

Gunite tanks W-6 and W-10 will be partially emptied of liquid contents to demonstrate the ability to empty these gunite tanks as a routine operation or in an emergency situation. Because of the radioactive content of the sludge, enough liquid ( $\sim 50,000$ gal) should be left in each tank to provide shielding.

\subsubsection{Early Action Schedule}

The gunite tanks in the South Tank Farm (W-5, W-6, W-7, W-8, W-9, and W-10) will have survey markers installed on one of the manways on each tank. The elevation of these markers will be monitored for any unusual fluctuations which may give an early warning of impending dome failure.

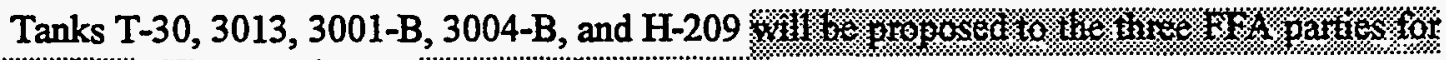

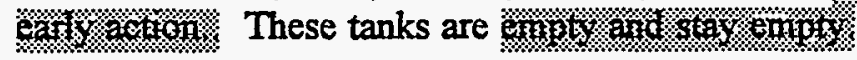

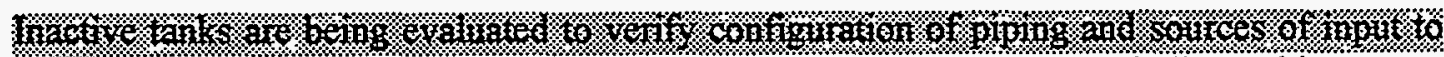

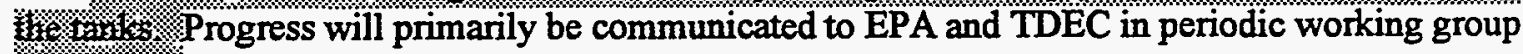
meetings.

A removal action is being considered for the Thorium Tank Farm (Tanks WC-5, WC-6, WC8, TH-1, TH-2, and TH-3). Some of the tanks receive inleakage and have sludge in them. Owing to the cost of maintaining these tanks and the period of time before these tanks are scheduled to enter the CERCLA process, a removal may be appropriate to begin the remediation process sooner. However, before a removal action can be initiated, all non-programmatic inputs must be stopped or diverted and the risk associated with these tanks must be shown to justify the action. Other tank farms are being evaluated for removal actions as well. 


\section{REFERENCES FOR CHAPTER 5}

1. Waste Characterization Data for the Oak Ridge National Laboratory Inactive Liquid LowLevel Radioactive Waste Tank Systems, DOE/OR/01-1159\&D1 (Supersedes ORNL/ER-80), Martin Marietta Energy Systems, Inc., Oak Ridge, Tennessee, June 1993.

2. Risk Characterization Data Manual for Inactive Liquid Low-Level Waste Tank Systems at Oak Ridge National Laboratory, Oak Ridge, Tennessee, ORNL/ER/Sub/90-LJ068/1, H\&R Technical Associates, Inc., Oak Ridge, Tennessee, September 1992.

3. Remediation Schedule for Inactive Liquid Low-Level Waste Storage Tanks at the Oak Ridge National Laboratory, Oak Ridge, Tennessee, DOE/OR/01-1138\&D1, H\&R Technical Associates, Inc., Oak Ridge, Tennessee, March 1993. 


\section{Appendix A}

\section{DATA SUMMARIES FOR CATEGORY A, B, AND C}

TANK SYSTEMS 

Exhibit A.1. Data summary for the MCS at Bldg. 2026.

A. Facility: 2026 [Radiochemical Processing Pilot Plant (RPPP)]

B. Tank Location: ORNL Bethel Valley Area, West of Bldg. 2026

C. Tank User Divisions: Analytical Chemistry, Waste Operations

D. Tank Data:

Tank Date of

No. Install.

Tank

Cap.

Material

FFA

F-1401

1993

IGV

1,900

SS

Category

Legend: $\quad$ AGV—above-ground vauit SS-stainless steel

IGV-in-ground vault CS-carbon steel

BT-buried tank

NA-not applicable

G-gunite

E. Original or Past Tank Usage:

The 2026 facility generates LLLW from analysis of samples at ORNL. The primary activities conducted within the facility include analysis of LLLW waste tank contents, reactor fuel analysis, and work for others. The facility is key to environmental characterization of materials considered by the FFA and other environmental compliance programs.

F. Current or Future Tank Usage:

This tank was installed in 1993 as part of the Bethel Valley LLW-CAT line item project and will be put in service in 1994.

G. System Component Characteristics:

Percent Doubly Contained Pipe in Facilities: $100 \%$

Length of Buried Piping: $\sim 900 \mathrm{ft}$

Percent Doubly Contained Buried Pipe: 100\%

Cathodic Protection for Buried Pipe: Yes

System Operation at Negative Pressure: Yes 
Exhibit A.2. Data summary for the TWRF storage tank.

A. Facility: 2649 [Transferred Waste Receiving Facility (TWRF)]

B. Tank Location: ORNL Bethel Valley, in Bldg. 2649

C. Tank User Division: Chemical Technology

D. Tank Data:

Tank Date of Tank

No. Install.

Cap.

Cap. Material

FFA

F-1701

$$
1993
$$

AGV

1,900

Category

Legend:

$$
\begin{array}{ll}
\text { AGV_above-ground vault } & \text { SS_-stainless steel } \\
\text { IGV_in-ground vault } & \text { CS_carbon steel } \\
\text { BT_buried tank } & \text { G_gunite } \\
\text { NA—not applicable } &
\end{array}
$$

SS

of Const.

A

E. Original or Past Tank Usage:

F-1701 is the central receiving point for all transported LLLW at ORNL.

F. Current or Future Tank Usage:

This tank is part of the newly constructed central station for receipt of bottled or trucked LLLW.

Initial operation of the facility is planned for FY 1995.

G. System Component Characteristics:

Percent Doubly Contained Pipe in Facilities: $100 \%$

Length of Buried Piping: $900 \mathrm{ft}$

Percent Doubly Contained Buried Pipe: 100\%

Cathodic Protection for Buried Pipe: Yes

System Operation at Negative Pressure: Yes 
Exhibit A.3. Data summary for the LLLW tank systems at Bldg. 3019.

A. Facility: 3019 [Radiochemical Processing Pilot Plant (RPPP)]

B. Tank Location: Bethel Valley, Cells 6 and 7 of Bldg. 3019

C. Tank User Divisions: Chemical Technology

D. Tank Data:

\begin{tabular}{|c|c|c|c|c|c|c|}
\hline $\begin{array}{l}\text { Tank } \\
\text { No. }\end{array}$ & $\begin{array}{l}\text { Date of Tank } \\
\text { Install. }\end{array}$ & Loc. & $\begin{array}{l}\text { Cap. } \\
\text { (gal) }\end{array}$ & $\begin{array}{l}\text { Material } \\
\text { of Const. }\end{array}$ & & $\begin{array}{c}\text { FFA } \\
\text { Category }\end{array}$ \\
\hline N-71 & Unknown & AGV & 240 & 304SS & & B \\
\hline $\begin{array}{l}\text { P-3 Unknowr } \\
\text { P-4 Unknowr }\end{array}$ & $\begin{array}{l}\text { AGV } \\
\text { AGV }\end{array}$ & & $\begin{array}{ll}197 & 347 S S \\
197 & 347 S S\end{array}$ & & $\begin{array}{l}\text { B } \\
\text { B }\end{array}$ & \\
\hline Legend: & $\begin{array}{l}\text { AGV_above-gr } \\
\text { IGV_-in-ground } \\
\text { BT_buried tank } \\
\text { NA-not applica }\end{array}$ & $\begin{array}{l}\text { and vault } \\
\text { ault } \\
\text { le }\end{array}$ & $\begin{array}{l}\text { SS_-stainles } \\
\text { CS_carbon } \\
\text { G_gunite }\end{array}$ & & & \\
\hline
\end{tabular}

E. Original or Past Tank Usage:

These tanks were used for collection of a variety of production waste process streams such as raffinates from extraction processes, overheads from evaporation processes, and others. In addition, laboratory wastes, such as liquids left after analyses and bench scale experimental processes were collected in the tanks. Also, any spills that might occur in the cells are jetted to these tanks.

F. Current or Future Tank Usage:

Same as above (E).

G. System Component Characteristics:

Percent Doubly Contained Pipe in Facilities: $100 \%$

Length of Buried Piping: $700 \mathrm{ft}$

Percent Doubly Contained Buried Pipe: 60\%

Cathodic Protection for Buried Pipe: Yes

System Operation at Negative Pressure: Yes 
Exhibit A.4. Data summary for the LLLW tank systems at Bldg. 3517.

A. Facility: 3517 [Fission Products Development Laboratory (FPDL)]

B. Tank Location: Bethel Valley, Cells 23 and 24 of Bldg. 3517

C. Tank User Division: Chemical Technology

D. Tank Data:

Tank

Date of Tank

Loc.

Cap.

Material

FFA

No.

Install.

S-223

1955

S-324

1955

S-523

1955

\section{IGV}

IGV

IGV

2500

1000

of Const.

Category

Legend:

AGV—above-ground vault

IGV-in-ground vault

BT-buried tank

NA-not applicable

304LSS

B

304LSS

304LSS

B

1000

B

$$
\begin{aligned}
& \text { SS_-stainless steel } \\
& \text { CS_carbon steel } \\
& \text { G_-gunite }
\end{aligned}
$$

E. Original or Past Tank Usage:

These tanks were used to collect production process wastes from a variety of operations. Wastes included supernate from cesium and strontium precipitation operations, raffinate from a cerium-144 extraction process, and general decontamination solutions that contained ${ }^{60} \mathrm{Co},{ }^{90} \mathrm{Sr},{ }^{192} \mathrm{Ir},{ }^{147} \mathrm{Pm}$, and ${ }^{137} \mathrm{Cs} /{ }^{134} \mathrm{Cs}$.

F. Current or Future Tank Usage:

Although less work is currently planned in this facility, future usage is expected to be similar to that in the past (i.e., fission product related) plus facility cleanup.

G. System Component Characteristics:

Percent Doubly Contained Pipe in Facilities: $100 \%$

Length of Buried Piping: $360 \mathrm{ft}$

Percent Doubly Contained Buried Pipe: $98 \%$

Cathodic Protection for Buried Pipe: Yes

System Operation at Negative Pressure: Yes 
Exhibit A.5. Data summary for the Evaporator Facility LLLW tank systems.

A. Facility: 2531 (Evaporator Facility)

B. Tank Location: C-1,C-2, W-21, W-22, and W-23 are located in Bethel Valley, north of Bldg. 2531.

C. Tank User Division: Waste Operations

D. Tank Data:

Tank Date of Tank

No. Install.

C-1 1964

C-2 1964

W-21 1979

W-22 1979

W-23 1979

Loc.

Cap.

(gal)

Material

FFA

IGV

50000

50000

50000

IGV

50000

of Const.

Category

Legend:

AGV-above-ground vault

IGV-in-ground vault

BT-buried tank

IGV

50000

$\begin{array}{ll}\text { SS } & \text { B } \\ \text { SS } & \text { B } \\ \text { SS } & \text { B } \\ \text { SS } & \text { B } \\ \text { SS } & \text { B }\end{array}$

NA-not applicable

SS-stainless steel

CS-carbon steel

G-gunite

E. Original or Past Tank Usage:

Tanks C-1, C-2, and W-21 through W-23 are used as feed or concentrate storage tanks for the LLLW evaporator located in Bldg. 2531.

F. Current or Future Tank Usage:

Current and future use remains unchanged for the tanks in the evaporator complex.

G. System Component Characteristics:

Percent Doubly Contained Pipe in Facilities: $100 \%$

Length of Buried Piping: $\sim 400 \mathrm{ft}$

Percent Doubly Contained Buried Pipe: $100 \%$

Cathodic Protection for Buried Pipe: All doubly contained piping has cathodic protection.

System Operation at Negative Pressure: Yes 
Exhibit A.6. Data summary for the LLLW tank systems at Bldg. 3544.

A. Facility: 3544 [Process Waste Treatment Plant (PWTP)]

B. Tank Location: Bethel Valley, in Bldg. 3544

C. Tank User Division: Waste Operations

D. Tank Data:

\begin{tabular}{|c|c|c|c|c|}
\hline Tank & Date of Tank & Cap. & \multirow{2}{*}{$\begin{array}{l}\text { Material } \\
\text { of Const. }\end{array}$} & \multirow{2}{*}{$\begin{array}{c}\text { FFA } \\
\text { Category }\end{array}$} \\
\hline No. & Install. & (gal) & & \\
\hline L-11 & 1975 & 400 & SS & B \\
\hline egend: & $\begin{array}{l}\text { AGV_-above-ground vaul } \\
\text { IGV_in-ground vault } \\
\text { BT_buried tank } \\
\text { NA-not applicable }\end{array}$ & $\begin{array}{l}\text { SS_stainl } \\
\text { CS_-carbo } \\
\text { G_-gunite } \\
\text { IF_-insid }\end{array}$ & & \\
\hline
\end{tabular}

E. Original or Past Tank Usage:

L-11 is used as a collection tank for the evaporator bottoms from the Process Waste Treatment Plant.

F. Current or Future Tank Usage:

Same as above (E).

G. System Component Characteristics:

Percent Doubly Contained Pipe in Facilities: $100 \%$

Length of Buried Piping: $900 \mathrm{ft}$

Percent Doubly Contained Buried Pipe: 0\%

Cathodic Protection for Buried Pipe: Yes

System Operation at Negative Pressure: Yes 
Exhibit A.7. Data summary for the New Hydrofracture Facility LLLW tank system.

A. Facility: NHF (New Hydrofracture Facility)

B. Tank Location: Melton Valley NHF area

C. Tank User Division: Waste Operations

D. Tank Data:

Tank Date of Tank

No. Install.

Material

FFA

$T-13$

1979

IGV

4000

SS

Category

Legend: $\quad$ AGV-above-ground vault SS-stainless steel

$$
\begin{aligned}
& \text { IGV-in-ground vault } \quad \text { CS-carbon steel } \\
& \text { BT-buried tank } \\
& \text { NA-not applicable }
\end{aligned}
$$

E. Original or Past Tank Usage:

Served as a waste tank for the New Hydrofracture Facility, which was used to solidify concentrated LLLW for disposal.

F. Current or Future Tank Usage:

Potential uses include pilot plant operations to develop new LLLW treatment processes and decontamination activities.

G. System Component Characteristics:

Percent Doubly Contained Pipe in Facilities: $100 \%$

Length of Buried Piping: $0 \mathrm{ft}$

Percent Doubly Contained Buried Pipe: NA

Cathodic Protection for Buried Pipe: NA

System Operation at Negative Pressure: Yes 
Exhibit A.8. Data summary for the Radiochemical Engineering Development Center LLLW tank systems.

A. Facility: REDC (Radiochemical Engineering Development Center)

B. Tank Location: ORNL Melton Valley, HFIR Area

C. Tank User Division: Chemical Technology, Waste Operations

D. Tank Data:

\begin{tabular}{|c|c|c|c|c|c|}
\hline $\begin{array}{l}\text { Tank } \\
\text { No. }\end{array}$ & $\begin{array}{l}\text { Date of Tank } \\
\text { Install. }\end{array}$ & $\underline{\text { Loc. }}$ & $\begin{array}{l}\text { Cap. } \\
\quad \text { (gal) }\end{array}$ & $\begin{array}{l}\text { Material } \\
\text { of Const. }\end{array}$ & $\begin{array}{c}\text { FFA } \\
\text { Category }\end{array}$ \\
\hline WC-20 & 1976 & IGV & 10000 & SS & B \\
\hline$F-111$ & 1962 & IGV & 125 & SS & B \\
\hline$F-126$ & 1962 & IGV & 1200 & SS & B \\
\hline$C-6-T$ & 1965 & IGV & 700 & SS & B \\
\hline B-2-T & 1965 & IGV & 1870 & SS & B \\
\hline B-3-T & 1965 & IGV & 1870 & SS & B \\
\hline Legend: & \multicolumn{2}{|c|}{$\begin{array}{l}\text { AGV_above-ground vault } \\
\text { IGV—in-ground vault } \\
\text { BT_-buried tank } \\
\text { NA_-not applicable }\end{array}$} & \multicolumn{2}{|c|}{$\begin{array}{l}\text { SS_-stainless steel } \\
\text { CS_carbon steel } \\
\text { G_-gunite }\end{array}$} & \\
\hline
\end{tabular}

E. Original or Past Tank Usage:

LLLW was produced from radiochemical operations designed to recover isotopes produced from irradiated HFIR targets and other sources. LLLW at REDC was primarily generated from disposal of spent off-gas scrubber solutions. Other sources included routine and nonroutine washdown of hot cells and other contaminated equipment. REDC is the major contributor of transuranic radionuclides in the LLLW system.

F. Current or Future Tank Usage:

Same as above (E).

G. System Component Characteristics:

Percent Doubly Contained Pipe in Facilities: 60\%

Length of Buried Piping: $7800 \mathrm{ft}$

Percent Doubly Contained Buried Pipe: 6\%

Cathodic Protection for Buried Pipe: All underground lines cathodically protected except three LLLW lines from Bldg. 7930 to the 7930 tank vault. The transfer line from Melton Valley to Bethel Valley is also protected. Approximately $90 \%$ of the system is protected.

System Operation at Negative Pressure: Yes 
Exhibit A.9. Data summary for the Melton Valley Storage Tank systems.

A. Facility: Melton Valley Storage Tanks

B. Tank Location: Melton Valley, Hydrofracture area

C. Tank User Division: Waste Operations

D. Tank Data:

Tank Date of Tank

No.

W-24 1980

W-25 $\quad 1980$

W-26 1980

W-27 1980

W-28 $\quad 1980$

W-29 1980

W-30 $\quad 1980$

W-31 1980

Install.
IGV-in-ground vault

BT-buried tank

NA-not applicable

Legend: AGV—above-ground vault

Loc.

IGV $\quad 50000$

IGV $\quad 50000$

IGV $\quad 50000$

IGV $\quad 50000$

IGV $\quad \mathbf{5 0 0 0 0}$

IGV $\quad 50000$

IGV 50000

IGV $\quad 50000$
Material

of Const.

FFA

\section{Category}

SS B

SS B

SS B

SS B

SS B

SS B

SS B

SS B

SS-stainless steel

CS-carbon steel

G-gunite

E. Tank Usage:

These tanks store the evaporator bottoms from the LLLW evaporators in Bethel Valley. This material, which includes transuranic waste, must be stored at ORNL until a DOE facility that can accept it becomes operational.

F. System Component Characteristics:

Percent Doubly Contained Pipe in Facilities: $100 \%$

Length of Buried Piping: $6,300 \mathrm{ft}$

Percent Doubly Contained Buried Pipe: 100\%

Cathodic Protection for Buried Pipe: Yes

System Operation at Negative Pressure: Yes 
Exhibit A.10. Data summary for the LLLW tank systems at Bldg. 3525.

A. Facility: 3525 (High Radiation Level Examination Laboratory)

B. Tank Location: ORNL Bethel Valley, South of Bldg. 3525

C. Tank User Division: Chemical Technology, Metals and Ceramics

D. Tank Data:

Tank Date of Tank

No. Install.

Cap. Material

FFA

F-201

1962

Loc.

(gal) of Const.

Category

F-501

1962

IGV

40

SS

C

Legend:

IGV

200 SS

$\mathrm{C}$

$$
\begin{array}{ll}
\text { AGV_-above-ground vault } & \text { SS_-stainless steel } \\
\text { IGV_in-ground vault } & \text { CS_carbon steel } \\
\text { BT_buried tank } & \text { G_-gunite } \\
\text { NA-not applicable } &
\end{array}
$$

E. Original or Past Tank Usage:

Bldg. 3525 provides for the post-irradiation mechanical disassembly of reactor components so that physical and metallurgical examinations can be conducted. LLLW is produced from the decontamination and cleamup of the hot cells used in the disassembly and examination process.

F. Current or Future Tank Usage:

Same as above (E).

G. System Component Characteristics:

Percent Doubly Contained Pipe in Facilities: $50 \%$

Length of Buried Piping: $290 \mathrm{ft}$

Percent Doubly Contained Buried Pipe: 0\%

Cathodic Protection for Buried Pipe: None

System Operation at Negative Pressure: Yes 
Exhibit A.11. Data summary for the Isotopes Circle Facilities LLLW tank systems.

A. Facility: Isotopes Circle

B. Tank Location: ORNL Bethel Valley, Isotopes Area

C. Tank User Division: Chemical Technology, Waste Operations

D. Tank Data:

Tank Date of Tank

No. Install.

Loc. (gal) of Const.

FFA

WC-10 1951

WC-2 1951

BT $2000 \quad$ SS

BT $\quad 1000$ SS

C

C

Legend: $\quad$ AGV_-above-ground vault SS-stainless steel

IGV-in-ground vault CS-carbon steel

BT-buried tank $\quad$ G-gunite

NA-not applicable

E. Original or Past Tank Usage:

Multigram quantities of radioisotopes were separated, purified, stored, and distributed in facilities ${ }^{\circ}$ serviced by the LLLW system. A wide range of radionuclides were produced. Isotopes were produced for use in medical, research, and industrial applications. Most waste was generated as a result of hot-cell and equipment decontamination. Waste includes residual solutions used for isotope separation, isotopes, and other contaminated liquids. The waste from the Hot Off-Gas Scrubber treatment facility is transferred via a pipe that intersects the WC-2 tank discharge line.

F. Current or Future Tank Usage:

Significant isotopes production in the facilities serviced by the LLLW system was terminated in FY 1990. However, the LLLW system contimues to collect waste from routine cleanup and washdown of hot cells and other components. The LLLW system will be used during formal cleanup and shutdown stabilization of the facility through FY 1998. Research and medical production activities will continue in a limited portion of these facilities for the foreseeable future. The Hot Off-Gas Scrubber waste will continue to be collected.

G. System Component Characteristics:

Percent Doubly Contained Pipe in Facilities: $100 \%$

Length of Buried Piping: $3900 \mathrm{ft}$

Percent Doubly Contained Buried Pipe: 0\%

Cathodic Protection for Buried Pipe: No

System Operation at Negative Pressure: Yes 
Exhibit A.12. Data summary for the HFIR LLLW tank systems.

A. Facility: HFIR (High Flux Isotopes Reactor)

B. Tank Location: ORNL Melton Valley Area, HFIR Area

C. Tank User Division: Research Reactors, Waste Operations

D. Tank Data:

Tank Date of Tank

No. Install.

Cap. Material

FFA

HFIR 1961

T-1 1963

T-2 1963

BT $\quad 13000$

BT $\quad 15000$

BT $\quad 15000$

SS

SS

SS

Category

Legend: $\quad$ AGV_-above-ground vault SS-stainless steel

$$
\begin{aligned}
& \text { IGV-in-ground vault } \quad \text { CS-carbon steel } \\
& \text { BT-buried tank } \\
& \text { NA-not applicable }
\end{aligned}
$$

E. Original or Past Tank Usage:

These LLLW systems service a major research reactor facility. LLLW from the HFIR primarily results from (1) regeneration and backwashing of primary and pool demineralizer systems, (2) sampling operations, (3) gaseous waste filter pit inleakage and condensation, and (4) stack drainage. Other waste is generated by routine maintenance and decontamination of contaminated equipment. When in operation, the HFIR is the primary source of ${ }^{60} \mathrm{Co}$ in the LLLW system.

F. Current or Future Tank Usage:

Same as above (E).

G. System Component Characteristics:

Percent Doubly Contained Pipe in Facilities: 100\%

Length of Buried Piping: $3000 \mathrm{ft}$

Percent Doubly Contained Buried Pipe: $0 \%$

Cathodic Protection for Buried Pipe: Transfer piping from T-1 and T-2 only.

System Operation at Negative Pressure: Yes 
Exhibit A.13. Data summary for the ORR/BSR LLLW tank system.

A. Facility: Oak Ridge Research Reactor/Bulk Shielding Reactor (ORR/BSR)

B. Tank Location: Bethel Valley, North of Bldg. 3047

C. Tank User Division: Research Reactors, Surplus Facilities

D. Tank Data:

Tank Date of Tank

No. Install.

Loc.

Cap. Material

FFA

WC-19 1955

BT

2250 SS

C

Legend: $\quad$ AGV—above-ground vault

IGV_-in-ground vault

BT-buried tank

NA—not applicable

SS-stainless steel

CS-carbon steel

G-gunite

E. Original or Past Tank Usage:

LLLW was produced from the regeneration of reactor pool and canal demineralizers at Bldgs. 3019 , 3001, 3042, 3004, and 3010. Also, the tanks received condensate from off-gas High Efficiency Particulate Air (HEPA) filter pits associated with these reactors.

F. Current or Future Tank Usage:

Although the reactors are not currently being operated, LLLW is produced from the regeneration of demineralizers at Bldgs. 3042, 30.19 , and 3001. Tank WC-19, which is an ES\&H tank, will continue to be used to process waste from regeneration of the demineralizers.

G. System Component Characteristics:

Percent Doubly Contained Pipe in Facilities: $100 \%$

Length of Buried Piping: $1200 \mathrm{ft}$

Percent Doubly Contained Buried Pipe: 0\%

Cathodic Protection for Buried Pipe: No

System Operation at Negative Pressure: Yes 
Exhibit A.14. Data summary for the LLLW tank system at Bldg. 3025.

A. Facility: 3025 (Irradiated Materials Examination and Testing Facility)

B. Tank Location: Bethel Valley, South of Bldg. 3025

C. Tank User Divisions: Waste Operations, Metals and Ceramics

D. Tank Data:

$\begin{array}{llll}\text { Tank } & \text { Date of Tank } & \text { Cap. Material } & \text { FFA } \\ \text { No. } & \underline{\text { Install. }} & \text { Loc. } & \text { (gal) of Const. }\end{array}$

$\begin{array}{llllll}\text { WC-3 } & 1951 & \text { BT } & 1000 & 347 S S & C\end{array}$

$\begin{array}{lll}\text { Legend: } & \text { AGV_above-ground vault } & \text { SS-stainless steel } \\ & \text { IGV_in-ground vault } & \text { CS-carbon steel } \\ \text { BT_buried tank } & \text { G_gunite } \\ \text { NA-not applicable } & \end{array}$

E. Original or Past Tank Usage:

WC-3 was used primarily to collect residuals from metallurgical sampling and analysis. The waste solutions came from etching, dissolution, and decontamination of particulate residue from physical property analysis (such as tensile and shear testing) of irradiated metals.

F. Current or Future Tank Usage:

Same as above (E).

G. System Component Characteristics:

Percent Doubly Contained Pipe in Facilities: $100 \%$

Length of Buried Piping: $250 \mathrm{ft}$

Percent Doubly Contained Buried Pipe: 0\%

Cathodic Protection for Buried Pipe: No

System Operation at Negative Pressure: Yes 
Exhibit A.15. Data summary for the LLLW tank system at Bldg. 2533/3504.

A. Facility: 2533/3504 (Cell Ventilation Filter Pit \& Geosciences Laboratory)

B. Tank Location: ORNL Bethel Valley, West of Bldg. 3504

C. Tank User Divisions: Environmental Science, Waste Operations

D. Tank Data:

Tank Date of Tank

No. Install.

Cap. Material

FFA

WC-7 1951

Loc.

(gal) of Const.

Category

Legend:

BT

1100 SS

C

$$
\begin{array}{ll}
\text { AGV_above-ground vault } & \text { SS-stainless steel } \\
\text { IGV_-in-ground vault } & \text { CS-carbon steel } \\
\text { BT_-buried tank } & \text { G_gunite } \\
\text { NA_not applicable } &
\end{array}
$$

E. Original or Past Tank Usage:

Waste solutions from health physics research of contaminated animals were stored in the LLLW tank. Original tank waste included fission products and other contaminated waste generated during animal contamination studies. LLLW from the Evaporator Complex Bldg. 2533 sump is transferred to the central LLLW system via the WC-7 discharge line.

F. Current or Future Tank Usage:

Current waste in Bldg. 3504 is generated from disposal of contaminated soil samples and from decontamination of equipment used in collecting soil samples. The tank discharge line will continue to receive condensate from the Evaporator Complex Bldg. 2533 sump.

G. System Component Characteristics:

Percent Doubly Contained Pipe in Facilities: $100 \%$

Length of Buried Piping: $1100 \mathrm{ft}$

Percent Doubly Contained Buried Pipe: 0\%

Cathodic Protection for Buried Pipe: No

System Operation at Negative Pressure: No 
Exhibit A.16. Data summary for the Radioactive (Hot) Off-Gas LLLW tank system.

A. Facility Name: Radioactive (Hot) Off-Gas also referred to as HOG (Hot Off-Gas Collection)

B. Tank Location: Bethel Valley, South of Bldg. 3503

C. Tank User Division: Chemical Technology

D. Tank Data:

Tank Date of Tank

No. Install.

WC-9 1952

Legend:
Cap. Material

Loc. $\quad$ (gal) of Const.

2150 SS

SS-stainless steel

CS_-carbon steel

G-gunite

$\begin{array}{ll}\text { BT } & 2150 \quad \text { SS } \\ \text { und vault } & \text { SS-stainless steel } \\ \text { vault } & \text { CS_carbon steel } \\ & \text { G_-gunite }\end{array}$

NA-not applicable

E. Original or Past Tank Usage:

Tank WC-9 received LLLW from Bldg. 3503. Building 3503 originally was a high-level radiation engineering laboratory. LLLW was generated by pilot plant studies. The tank also received waste from the Hot Off-Gas System, which collects condensate from the hot off-gas and cell ventilation gaseous waste collection systems.

F. Current or Future Tank Usage:

WC-9 currently receives condensate from the Hot Off-Gas Pot.

G. System Component Characteristics:

Percent Doubly Contained Pipe in Facilities: 0\%

Length of Buried Piping: $125 \mathrm{ft}$

Percent Doubly Contained Buried Pipe: 0\%

Cathodic Protection for Buried Pipe: None

System Operation at Negative Pressure: No 
Exhibit A.17. Data summary for the LLLW tank system at Bldg. 2026.

A. Facility Name: 2026 [High Radiation Level Analytical Laboratory (HRLAL)]

B. Tank Location: ORNL Bethel Valley Area, East of Bldg. 2026

C. Tank User Divisions: Analytical Chemistry, Waste Operations

D. Tank Data:

Tank Date of Tank

No. Install.

2026A

1962

Legend:

$$
\begin{array}{ll}
\text { AGV_above-ground vault } & \text { SS-stainless steel } \\
\text { IGV_in-ground vault } & \text { CS_carbon steel } \\
\text { BT-buried tank } & \text { G-gunite } \\
\text { NA-not applicable } &
\end{array}
$$

Loc. (gal) of Const.

E. Original or Past Tank Usage:

The 2026 facility provided analytical sample analysis for various programs at ORNL. LLLW was generated upon disposal of various samples once analysis was completed and from routine washdown and decontamination of hot cells and other contaminated equipment.

F. Current or Future Tank Usage:

This tank is being replaced by new tank F-1401 and will be removed from service in 1995 .

G. System Component Characteristics:

Percent Doubly Contained Pipe in Facilities: 0\%

Length of Buried Piping: $900 \mathrm{ft}$

Percent Doubly Contained Buried Pipe: 0\%

Cathodic Protection for Buried Pipe: No

System Operation at Negative Pressure: Yes 
Exhibit A.18. Data summary for the LLLW tank system at Bldg. 3026D.

A. Facility Name: 3026D (Segmenting Hot Cell Facility)

B. Tank Location: Melton Valley South Tank Farm

C. Tank User Divisions: Waste Operations, Metals and Ceramics

D. Tank Data:

Tank

Date of Tank

Cap.

Material

FFA

No. Install.

Loc. (gal) of Const.

Category

W-16 1951

BT

$1000347 \mathrm{SS}$

C
Legend: $\quad$ AGV—above-ground vault SS-stainless steel
IGV_-in-ground vault CS-carbon steel
BT-buried tank
NA-not applicable
G-gunite

E. Original or Past Tank Usage:

Tank W-16 serves Bldg. 3026D in the Isotopes Complex. Multigram quantities of radioisotopes were separated, purified, stored, and distributed in facilities serviced by the LLLW system. A wide range of radionuclides was produced. Isotopes were produced for use in medical, research, and industrial applications. Most waste was generated as a result of routine and nonroutine hot-cell and equipment decontamination. Waste includes residual solutions used for isotope separation, trace quantities of isotopes, and other contaminated liquids.

F. Current or Future Tank Usage:

Potential use for decontamination of Bldg. 3026D.

G. System Component Characteristics:

Percent Doubly Contained Pipe in Facilities: $100 \%$

Length of Buried Piping: $550 \mathrm{ft}$

Percent Doubly Contained Buried Pipe: 0\%

Cathodic Protection for Buried Pipe: No

System Operation at Negative Pressure: Yes 
Appendix B

DATA SUMMARIES FOR CATEGORY D TANK SYSTEMS 

Exhibit B.1. Data summary for South Tank Farm Category D LLLW tank systems.

A. Tanks Located at: Bethel Valley, South Tank Farm (W-5, W-6, W-7, W-8, W-9, W-10, W-11, W-17); south of the South Tank Farm (W-18, W-19, and W-20).

B. Responsible Division: Environmental Restoration

C. Tank Data Table:

\begin{tabular}{|c|c|c|c|c|c|c|}
\hline Tank No. & $\begin{array}{l}\text { Date of } \\
\text { Install. }\end{array}$ & Tank Loc. & Cap. (gal) & $\begin{array}{l}\text { Material } \\
\text { of Const. }\end{array}$ & $\begin{array}{l}\text { Double } \\
\text { Ctnment }\end{array}$ & $\begin{array}{c}\text { Cathodic } \\
\text { Prot. }\end{array}$ \\
\hline$W-5$ & 1943 & BT & 170000 & G & no & $\mathrm{NA}$ \\
\hline W-6 & 1943 & BT & 170000 & G & no & NA \\
\hline$W-7$ & 1943 & BT & 170000 & G & no & $\mathrm{NA}$ \\
\hline W-8 & 1943 & BT & 170000 & G & no & $\mathrm{NA}$ \\
\hline W-9 & 1943 & BT & 170000 & $\mathrm{G}$ & no & NA \\
\hline$W-10$ & 1943 & BT & 170000 & $G$ & no & NA \\
\hline W-11 & 1943 & BT & 1500 & G & no & $\mathrm{NA}$ \\
\hline W-17 & 1951 & BT & 1000 & SS & no & no \\
\hline W-18 & 1951 & BT & 1000 & SS & no & no \\
\hline W-19 & 1955 & BT & 2250 & SS & no & no \\
\hline W-20 & 1955 & BT & 2250 & SS & no & no \\
\hline
\end{tabular}

Legend: AGV-above ground vault SS-stainless steel IGV-in-ground vault

BT-buried tank

CS-carbon steel

NA-not applicable

G-gunite

D. Original or Past Tank Usage:

Tanks W-5 through W-10 were constructed in 1943 for long-term storage of LLLW. Because of the expanding needs of the Laboratory, the capacity of the tanks proved inadequate. The waste was directed to an evaporator between 1949 and 1954 and from 1959 until the tanks were taken out of service in 1980. Between 1953 and 1959 the waste was sent to open waste pits.

Tank W-11 was constructed in 1943 to serve as a waste collection and monitoring tank for research laboratories in BIdg. 3550. The tank was removed from service in 1948 because of leaks.

Tanks W-17 and W-18 served as waste tanks for isotope production in Bldg. 3026.

Tanks W-19 and W-20 were used to collect waste produced from recovery and reprocessing of uranium and other nuclear material from the Metal Recovery Facility in Bldg. 3505. The tanks were removed from service in 1960. 
E. Waste Characterization:

The results of a previous sampling campaign revealed that Tanks W-5 through W-10 contain sludge with transuranics and toxic metals. In addition, most of these tanks contain organics. Tank W-11 contains primarily low-level waste in aqueous form.

The results of a previous sampling campaign revealed that tanks W-19 and W-20 are empty.

The results of the 1992-1993 sampling campaign showed that contaminant levels in tanks $\mathrm{W}-17$ and $\mathrm{W}-18$ are very low. 
Exhibit B.2. Data summary for Old Hydrofracture Facility Category D LLLW tank systems.

A. Tanks Located at: Melton Valley Hydrofracture Area

B. Responsible Division: Environmental Restoration

C. Tank Data Table:

$\begin{array}{ccccccc}\text { Tank No. } & \begin{array}{c}\text { Date of } \\ \text { Install. }\end{array} & \text { Tank Loc. } & \underline{\text { Cap. (gal) }} & \begin{array}{c}\text { Material } \\ \text { of Const. }\end{array} & \begin{array}{c}\text { Double } \\ \text { Ctnment }\end{array} & \begin{array}{c}\text { Cathodic } \\ \text { Prot. }\end{array} \\ \text { T1 } & 1963 & \text { BT } & 15000 & \text { CS } & \text { no } & \text { yes * } \\ \text { T2 } & 1963 & \text { BT } & 15000 & \text { CS } & \text { no } & \text { yes * } \\ \text { T3 } & 1963 & \text { BT } & 25000 & \text { CS/RL } & \text { no } & \text { yes * } \\ \text { T4 } & 1963 & \text { BT } & 25000 & \text { CS/RL } & \text { no } & \text { yes * } \\ \text { T9 } & 1963 & \text { BT } & 13000 & \text { CS } & \text { no } & \text { yes * }\end{array}$

Legend: AGV-above ground vault SS-stainless steel

IGV-in-ground vault $\quad$ CS-carbon steel

BT-buried tank

NA-not applicable

G-gunite

RL-rubber lining

* The cathodic protection system is not operational.

D. Original or Past Tank Usage:

Tanks T1 through T4 and T9 were used during the Old Hydrofracture Facility operation to store liquid waste until it was ready to be blended with grout, before waste injection by hydrofracture. The Old Hydrofracture Facility operations were discontinued in 1980.

E. Waste Characterization:

The results of a previous sampling campaign indicate that the Old Hydrofracture Facility tanks (T-1 through T-4 and T-9) contain soft sludge with high transuranic and toxic metal concentrations. 
Exhibit B.3. Data summary for the North Tank Farm Category D LLLW tank systems.

A. Tanks Located at: Bethel Valley, North Tank Farm Area

B. Responsible Division: Environmental Restoration

C. Tank Data Table:

\begin{tabular}{|c|c|c|c|c|c|c|}
\hline Tank No. & $\begin{array}{l}\text { Date of } \\
\text { Install. }\end{array}$ & Tank Loc. & Cap. (gal) & $\begin{array}{l}\text { Material } \\
\text { of Const. }\end{array}$ & $\begin{array}{l}\text { Double } \\
\text { Ctnment }\end{array}$ & $\begin{array}{c}\text { Cathodic } \\
\text { Prot. }\end{array}$ \\
\hline W-1 & 1943 & BT & 4800 & G & no & NA \\
\hline W-2 & 1943 & BT & 4800 & G & no & NA \\
\hline W-3 & 1943 & BT & 42500 & $\mathbf{G}$ & no & $\mathrm{NA}$ \\
\hline$W-4$ & 1943 & BT & 42500 & G & no & NA \\
\hline W-13 & 1945 & BT & 2000 & SS & no & no \\
\hline W-14 & 1945 & BT & 2000 & SS & no & no \\
\hline W-1A & 1951 & $\mathrm{BT}$ & 4000 & SS & no & no \\
\hline W-15 & 1945 & BT & 2000 & SS & no & . \\
\hline
\end{tabular}

Legend: AGV-above-ground vault SS-stainless steel IGV-in-ground vault

BT-buried tank CS—carbon steel

NA-not applicable

G-gunite

D. Original or Past Tank Usage:

Tanks W-1 through W-4 and W-1A received waste from Bldg. 3019, a radiochemical processing facility. The principal radionuclides in the waste were cesium, strontium, and transuranics. Tanks W-1 through W-4 were taken out of service in the early 1960s, and tank W-1A was taken out of service in 1986 because of leaks. The tanks were emptied when removed from service.

Tanks W-13, W-14, and W-15 were connected to the metal waste drains from the Radiochemical Processing Facility, Bldg. 3019, but also collected chemical waste from recovery of fission products. The tanks were taken out of service in 1958.

E. Waste Characterization:

The results of a previous sampling campaign revealed that the North Tank Farm varies from tanks with only liquids (W-1, W-1A, W-2, W-13, W-14, and W-15) to tanks that contain a liquid phase and a sludge with transuranic and toxic metals (W-3 and W-4). 
Exhibit B.4. Data summary for the 3500 Area Category D LLLW tank systems.

A. Tank Group Location: Bethel Valley, 3500 Area

B. Responsible Division: Environmental Restoration

C. Tank Data Table:

\begin{tabular}{|c|c|c|c|c|c|c|}
\hline Tank No. & $\begin{array}{l}\text { Date of } \\
\text { Install. }\end{array}$ & Tank Loc. & Cap. (gal) & $\begin{array}{l}\text { Material } \\
\text { of Const. }\end{array}$ & $\begin{array}{l}\text { Double } \\
\text { Ctnment }\end{array}$ & $\begin{array}{c}\text { Cathodic } \\
\text { Prot. }\end{array}$ \\
\hline TH-1 & 1948 & $\mathrm{BT}$ & 2500 & SS & no & no \\
\hline TH-2 & 1952 & BT & 2400 & SS & no & no \\
\hline TH-3 & 1952 & BT & 3300 & SS & no & no \\
\hline TH -4 & 1952 & BT & 14000 & G & no & NA \\
\hline$S-424$ & 1955 & IGV & 500 & SS/GL & yes & no \\
\hline H-209 & 1961 & BT & $2500^{*}$ & SS & no & no \\
\hline WC-5 & 1952 & BT & 1000 & SS & no & no \\
\hline WC-6 & 1952 & BT & 500 & SS & no & no \\
\hline WC-8 & 1952 & BT & 1000 & SS & no & no \\
\hline
\end{tabular}

Legend: AGV-above ground vault

SS-stainless steel

IGV-in-ground vault

CS-carbon steel

BT-buried tank

G-gunite

NA-not applicable

* - estimated

D. Original or Past Tank Usage:

Tanks TH-1, TH-2, and TH-3, received waste from the irradiated thorium and uranium pilot development plant development projects in Bldg. 3503. TH-4 received waste from thorium and uranium projects in Bldg. 3550. The tanks were taken out of service in 1970.

S-424 was used to collect highly corrosive chloride-bearing supernate from a precipitation operation.

Tanks WC-5, WC-6, and WC-8 received waste from development projects in Bldgs. 3508, 3541, and 3592.

E. Waste Characterization:

Tanks TH-1, TH-2, and TH-3 contain little or no sludge. The liquid phase contains low levels of radioactivity.

Tank TH-4 is a medium-sized gunite tank that contains large quantities of sludge but is not known to leak.

Tanks S-424, H-209, WC-5, WC-6, and WC-8 were sampled in FY 92 and early FY 93. Tank S424 contains no liquids and will be further characterized as part of the RI/FS process. Tank H-209 contains no sludge, and its liquid has low levels of chemical and radiological contaminants. Tanks WC-5, WC-6, and WC-8 contain no sludge, and their liquids have very low levels of chemical and radiological contaminants. 
Exhibit B.5. Data summary for the Isotopes Circle Category D LLLW tank systems.

A. Tanks Located at: Bethel Valley, Isotopes Circle. Tank W-II is located under the floor slab in the east airlock of Bldg. 3028.

'B. Responsible Division: Environmental Restoration

C. Tank Data Table:

\begin{tabular}{|c|c|c|c|c|c|c|}
\hline Tank No. & $\begin{array}{l}\text { Date of } \\
\text { Install. }\end{array}$ & Tank Loc. & Cap. (gal) & $\begin{array}{l}\text { Material } \\
\text { of Const. }\end{array}$ & $\begin{array}{l}\text { Double } \\
\text { Ctnment }\end{array}$ & $\begin{array}{c}\text { Cathodic } \\
\text { Prot. }\end{array}$ \\
\hline W-II & 1959 & BT & 500 & SS & no & no \\
\hline WC-1 & 1950 & BT & 2150 & SS & no & no \\
\hline Legend: & \multicolumn{2}{|c|}{$\begin{array}{l}\text { AGV_-above ground vault } \\
\text { IGV-in-ground vault } \\
\text { BT-buried tank } \\
\text { NA-not applicable }\end{array}$} & \multicolumn{2}{|c|}{$\begin{array}{l}\text { SS-stainless steel } \\
\text { CS_carbon steel } \\
\text { G_gunite }\end{array}$} & & \\
\hline
\end{tabular}

D. Original or Past Tank Usage:

Tank W-1I was used to collect waste liquids from isotope recovery operations in Bldg. 3028. Although the actual date is uncertain, the tank was removed from service by 1987.

WC-1 was used to collect and monitor process liquid waste from isotopes production and development laboratories in Bldgs. 3038, 3028, 3029, 3030, 3031, 3032, 3033, 3047, the filter in Bldg. 3110, the 3039 stack, and the scrubber in 3092. The tank was taken out of service in 1968 because of a leaking discharge line.

E. Waste Characterization:

Tank WC-1 contains little or no sludge. The liquid contents have been removed. Tank W-1I has no liquids, and its sludge contains high levels of aipha contamination. 
Exhibit B.6. Data summary for the 4500 Area Category D LLLW tank systems.

A. Tanks Located at: Bethel Valley, 4500 Area

B. Responsible Division: Environmental Restoration

C. Tank Data Table:

\begin{tabular}{|c|c|c|c|c|c|c|}
\hline Tank No. & $\begin{array}{l}\text { Date of } \\
\text { Install. }\end{array}$ & Tank Loc. & Cap. (gal) & $\begin{array}{l}\text { Material } \\
\text { of Const. }\end{array}$ & $\begin{array}{l}\text { Double } \\
\text { Ctnment }\end{array}$ & $\begin{array}{c}\text { Cathodic } \\
\text { Prot. }\end{array}$ \\
\hline 4501-P & unknown & IGV & 100 & SS & yes & NA \\
\hline T-30 & 1961 & IGV & 825 & SS & yes & NA \\
\hline
\end{tabular}
Legend: AGV—above ground vault SS-stainless steel IGV-in-ground vault $\quad$ CS-carbon steel BT-buried tank G-gunite NA-not applicable

D. Original or Past Tank Usage:

Tank 4501-P was used to store waste from the plutonium recovery loop experiment and other waste from experiments in Bldg. 4501. The tank was flushed and drained in 1990.

Tank T-30 was used to store radioactive materials for the Curium Recovery Facility, Bldg. 4507, which later became the High Radiation Level Chemical Recovery Facility. The out-of- service date for the tank is unknown.

E. Waste Characterization:

The liquid contents were removed from Tank T-30 in Sept. 1993. Tank 4501-P is empty. 
Exhibit B.7. Data summary for the 3587 Area Category D LLLW tank systems.

A. Tank Located at: South of Bldg. 3587

B. Responsible Divisions: Environmental Restoration, Waste Management

C. Tank Data Table:

\begin{tabular}{|c|c|c|c|c|c|c|}
\hline Tank No. & $\begin{array}{l}\text { Date of } \\
\text { Install. }\end{array}$ & Tank Loc. & Cap. (gal) & $\begin{array}{l}\text { Material } \\
\text { of Const. }\end{array}$ & $\begin{array}{l}\text { Double } \\
\text { Ctnment }\end{array}$ & $\begin{array}{c}\text { Cathod } \\
\text { Prot. }\end{array}$ \\
\hline WC-11 & 1951 & BT & 4000 & SS & no & no \\
\hline WC-12 & 1947 & BT & 700 & SS & no & no \\
\hline WC-13 & 1951 & BT & 1000 & SS & no & no \\
\hline WC-14 & 1951 & BT & 1000 & SS & no & no \\
\hline WC-15 & 1951 & BT & 1000 & SS & no & 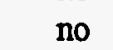 \\
\hline WC-17 & 1951 & BT & 1000 & SS & no & \\
\hline
\end{tabular}

Legend: AGV—above ground vault

SS-Stainless steel

IGV-in-ground vault

CS_carbon steel

BT-buried tank

G-gunite

NA-not applicable

GL-glass lined

D. Original or Past Tank Usage:

Tanks WC-11, WC-12, WC-13 and WC-14 were used as waste tanks for the 4500 complex.

Tanks WC-15 and WC-17 were used to collect LLLW from research laboratories in Bldg. 4500. Tanks WC-15 and WC-17 were taken out of service in the 1960s (exact date unknown) because of leaks.

E. Waste Characterization:

Tanks WC-11, WC-13, and WC-14 were sampled in FY 92 and early FY 93. Tanks WC-11 and WC-13 contain a thin, floating organic layer. The liquid is radioactive. Tank WC-14 contains liquid contaminated primarily with ${ }^{137} \mathrm{Cs}$.

Tanks WC-15, and WC-17 contain little or no sludge. The liquid phase contains low levels of radioactivity with an organic layer within the liquid phase. 
Exhibit B.8. Data summary for Melton Valley Area Category D LLLW tank systems.

A. Tanks Located at: Melton Valley Area

B. Responsible Division: Environmental Restoration

C. Tank Data Table:

\begin{tabular}{|c|c|c|c|c|c|c|}
\hline Tank No. & $\begin{array}{l}\text { Date of } \\
\text { Install. }\end{array}$ & Tank Loc. & $\frac{\text { Cap. }}{\text { (gal) }}$ & $\begin{array}{l}\text { Material } \\
\text { of Const. }\end{array}$ & $\begin{array}{l}\text { Double } \\
\text { Ctnment }\end{array}$ & $\begin{array}{c}\text { Cathodi } \\
\text { Prot. }\end{array}$ \\
\hline T14 & 1979 & BT & 48500 & C & no & no \\
\hline 7503-A & 1962 & IGV & 11000 & SS & yes & NA \\
\hline 7560 & 1957 & BT & 1000 & SS & no & no \\
\hline 7562 & 1957 & BT & 12000 & SS & no & no \\
\hline
\end{tabular}
Legend: AGV - above ground vault $\quad$ SS-stainless steel
IGV-in-ground vault $\quad$ CS-carbon steel
BT-buried tank
NA-not applicable $\quad \mathbf{R}$-rubber lining

D. Original or Past Tank Usage:

Tank T-14 was used as an overflow emergency waste tank for the new Hydrofracture Facility.

The removal-from-service date is unknown.

Tank 7503-A was a waste holding tank for the Molten Salt Reactor Experiment. The out-ofservice date is unknown.

Tank 7560 was originally used as a waste tank for the Homogenous Reactor Experiment (HRE) and later used as the clean vapor condensate tank for HRE-2. Tank 7562 was used as a waste tank for the HRE. The tanks were removed from active service in 1961.

E. Waste Characterization:

The results of a previous sampling campaign revealed that tank 7562 contains an aqueous phase with little or no sludge and tank 7560 is empty.

Tank 7503-A was sampled in FY 93 and was found to be empty except for a very thin layer of dry sludge. Tank T-14 contains low levels of chemicals and radiological contaminants. 
Exhibit B.9. Data summary for the 3000 Area Category D LLLW tank systems.

A. Tank Location: Bethel Valley, 3000 Area

B. Responsible Divisions: Environmental Restoration, Waste Management

C. Tank Data Table:

\begin{tabular}{|c|c|c|c|c|c|c|}
\hline Tank No. & $\begin{array}{l}\text { Date of } \\
\text { Install. }\end{array}$ & Tank Loc. & Cap. (gal) & $\begin{array}{l}\text { Material } \\
\text { of Const. }\end{array}$ & $\begin{array}{c}\text { Double } \\
\text { Ctnment }\end{array}$ & $\begin{array}{c}\text { Cathodic } \\
\text { Prot. }\end{array}$ \\
\hline $3001-B$ & 1943 & BT & $75^{*}$ & SS & no & no \\
\hline $3003-A$ & 1943 & BT & 16000 & G & no & NA \\
\hline 3004-B & 1956 & IGV & 30 & SS & yes & NA \\
\hline 3013 & 1949 & BT & 400 & SS & no & no \\
\hline $3002-A$ & 1943 & IGV & 1600 & SS & no & no \\
\hline WC-4 & 1944 & BT & 1700 & SS & no & no \\
\hline
\end{tabular}
Legend: AGV—above ground vault $\quad$ SS-stainless steel IGV-in-ground vault $\quad$ CS-carbon steel BT-buried tank NA-not applicable G-gunite GL-glass lined *_estimated

D. Original or Past Tank Usage:

Tank 3001-B is thought to have been a hold-up tank for hot lab drains in Bldg. 3001. The tank was taken out of service in 1965.

Tank 3003-A received LLLW from three cells and a stack in Bldg. 3003. Building 3003 was the air-handling building for the graphite reactor (Bldg. 3001). Because it was the air handling system, condensate from this equipment is expected to be contaminated with low levels of fission products. The tank was taken out of service in 1965.

Tank 3004-B was a waste-holding tank for the Low Intensity Test Reactor. The out-of-service date is unknown.

Tank 3013 is connected to the drains in Bldg. 3013. Building 3013 was originally an environmental processing laboratory that dealt with low-level contaminated environmental samples. The out-of-service date is unknown.

Tank 3002-A was used to collect liquid condensate from Bldg. 3002. Building 3002 was the filter house for the Old Graphite Reactor. The removal-from-service date is unknown. 
Tank WC-4 was used as a waste tank for Bldg. 3026. Wastes were primarily generated from the Roll Up Process, which involved dissolving uranium targets and extracting isotopes. The tank was taken out of service in the 1950s.

E. Waste Characterization:

Tank 3001-B contains $<1$ in. of liquid containing low levels of chemical and radiological contaminants. Tank 3003-A contains liquid and sludge with chemical and radiological contaminants. Tank 3004-B is a very small tank containing liquid with low levels of chemical and radiological contaminants. Tank 3013 contains liquid with very low chemical and radiological contamination. Tank 3002-A contains liquid and a thin sludge layer with very low levels of chemical and radiological contaminants. Tank WC-4 contains liquids with low levels of radiological and chemical contaminants. 
Exhibit B.10. Data summary for the 3525 Area Category D LLLW tank systems.

A. Tank Location: Bethel Valley, Southwest of Bldg. 3525

B. Responsible Division: Waste Management

C. Tank Data Table:

$\begin{array}{ccccccc}\text { Tank No. } & \begin{array}{c}\text { Date of } \\ \text { Install. }\end{array} & \text { Tank Loc. } & \underline{\text { Cap. (gal) }} & \begin{array}{c}\text { Material } \\ \text { of Const. }\end{array} & \begin{array}{c}\text { Double } \\ \text { Ctnment }\end{array} & \begin{array}{c}\text { Cathodic } \\ \text { Prot. }\end{array} \\ \text { W-12 } & 1947 & \text { BT } & 700 & \text { SS } & \text { no } & \text { no }\end{array}$

Legend: AGV-above ground vault IGV-in-ground vault BT-buried tank NA - not applicable SS-stainless steel CS-carbon steel G-gunite GL-glass lined

D. Original or Past Tank Usage:

Tank W-12 is designed to receive waste from the examination of reactor components in Bldg. 3525 from tanks F-501 and F-201. The tank system has been repaired and will be returned to service upon approval of a waiver for short-term operation. 
Exhibit B.11. Data summary for the Bldg. 3047 LLLW tank systems.
A. Tank Location: ORNL Bethel Valley, Isotopes Area, Bldg. 3047.
B. Responsible Division: Environmental Restoration
C Tank Data Table:

Tank Date of Tank

No. Install. Loc.

Cap. Material Double Cathodic

$\begin{array}{llllll}\text { LA-104 } 1960 & \text { IGV } & 296 & \text { SS } & \text { Yes } & \text { NA }\end{array}$
Legend: AGV—above-ground vault SS--stainless steel
IGV-in-ground vault CS-carbon steel
BT-buried tank G-gunite

NA-not applicable

D. Original or Past Tank Usage:

Multigram quantities of radioisotopes were separated, purified, stored, and distributed in facilities serviced by the LLLW system. A wide range of radionuclides were produced. Isotopes were produced for use in medical, research, and industrial applications. Most waste was generated as a result of hot-cell and equipment decontamination. Waste includes residual solutions used for isotope separation, isotopes, and other contaminated liquids.

E. Waste Characterization: 
DOE/OR/01-1276\&D2

ORNL/ER-242\&D2

\section{DISTRIBUTION}

1. M. Belvin

2. H. L. Boston

3. T. W. Burwinkle

4. A. D. Clay

5. C. E. Devore

6-8. J. T. Etheridge

9. C. E. Frye

10. H. R. Gaddis

11. P. J. Halsey

12. M. W. Kohring

13. A. M. Krichinsky

14-16. D. M. Matteo

17-19. T. H. Monk

20. K A Morgan

21-22. P. T. Owen

23. B. D. Patton

24-25. M. R. Peet

26. E. C. Phillips

27. S. M. Robinson

28. C. B. Scott

29. L. H. Stinton

30. R. J. Vedder

31. R. M. Wham

32. M. L. Whitehead

33. P. S. Wood

34. Central Research Library

35. Engineering Document Management Center

36. ORNL ER Document Management Center

37. Central ER Document Management Center

38. Laboratory Records Department

39. ORNL Patent Section

40. Office of Assistant Manager for Energy Research and Development, DOE Oak Ridge Operations Office, P.O. Box 2001, Oak Ridge, TN 37831-8600

41-42. M. Singleton, H\&R Technical Associates, Inc, P.O. Box 4159, Oak Ridge, TN 37831-4159

43. C. Mims, DOE Oak Ridge Operations Office, P.O. Box 2001, Oak Ridge, TN 37831-8541

44. L. L. Radcliffe, DOE Oak Ridge Operations Office, P.O. Box 2001, Oak Ridge, TN 378318541

45. L. C. M. Roddye, DOE Oak Ridge Operations Office, P.O. Box 2001, Oak Ridge, TN 378318541

46. R. C. Sleeman, DOE Oak Ridge Operations Office, P.O. Box 2001, Oak Ridge, TN 378318541

47. Douglas Underwood, DOE Oak Ridge Operations Office, P.O. Box 2001, Oak Ridge, TN 37831-8541

48-49. Office of Scientific and Technical Information, P.O. Box 62, Oak Ridge, TN 37831 